\title{
Modern biotechnology in optimizing plant waste utilization
}

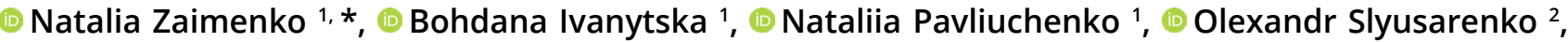

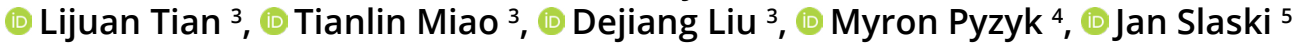 \\ 1 M.M. Gryshko National Botanical Garden, National Academy of Sciences of Ukraine, Tymiryazevska str. 1, 01014 Kyiv, Ukraine; \\ *zaimenkonv@ukr.net \\ 2 Botanical Garden of the Odesa I.I. Mechnikov National University, Frantsuzsky blvd. 48/50, 65058 Odesa, Ukraine \\ ${ }^{3}$ China-Ukraine Agriculture \& Forestry Technology Development and Application International Cooperation Joint Lab, Jiamusi \\ University, 154007 Jiamusi, China \\ ${ }^{4}$ United Institute of Modern Technologies, Edmonton, T5N 3C1 Alberta, Canada \\ ${ }^{5}$ Bio-Industrial Services Division, InnoTech Alberta, Vegreville, T9C 1T4 Alberta, Canada
}

Received: 29.06 .2020 | Accepted: 12.11 .2020 | Published: 30.12 .2020

\begin{abstract}
The study aimed to develop a modern, cheap, and environmentally safe technology for the disposal of plant waste, with the participation of the most active microorganisms-destructors.

The microorganisms' ability to help transform plant waste into viable, fertile soil was extensively studied. We selected strains of micromycetes Penicillium roseopurpureum, Trichoderma hamatum, T. koningii, Alternaria alternata, and bacteria of the genus Cytophaga, which are characterized by high growth rate and the absence of phytotoxicity. To accelerate microorganism development, we used silicon-containing mineral analcime, which contained immobilized spores of micromycetes and bacterial cells' suspensions. Modified analcime was added to the waste in a ratio of $10: 1$. The plant remains prepared in this method were analyzed under conditions of both model and vegetation experiments.

An evidence for the expediency of using the silicon-containing mineral analcime as a starting substrate for immobilization of spores and suspension of bacterial cells in the culture fluid was provided. The microorganisms involved in the experiment showed a positive result in transforming plant waste during the 30-day observation period. The highest destructive activity against apple and grape waste is characteristic for the $T$. hamatum strain, for beet waste - $P$. roseopurpureum. The species-specificity of these destructive microorganisms on plant growth processes was proved. The maximum growth of corn sprouts in apple waste was detected by inoculation with $T$. koningii spores, grape waste - T. hamatum, and beet waste - a mixture of micromycetes with a Cytophaga sp. suspension. The optimal duration of plant waste transformation using analcime, inoculated with microorganisms, is 20-30 days. In the indoor farming conditions, the standard for utilizing the modified vegetable waste placement was $10 \%$ of the total volume of a substrate during the preparation of soil mixes.

The environmental safety of plant waste after their destruction was confirmed. The presence of a siliconcontaining mineral in the mixture leads to increased growth and plant development, optimization of the agrophysical, agrochemical, and biological parameters of the soil, reducing soil fatigue, and increasing fertility.
\end{abstract}

Keywords: plant waste, destructive microorganisms, silicon-containing minerals, soil ecosystem 


\section{Introduction}

One of the most pressing issues of today, on which humanity's future depends, involves major environmental challenges. The beginning of the $20^{\text {th }}$ century is marked by the development of a global environmental crisis. Due to population growth and active manufacturing and due to rapid intensification of the industry under shallow environmental awareness conditions, there has been a loss of natural resources and the biosphere's ability to 'self-heal' and 'self-purify'. The current development of civilization, science, and technology has resulted in the rapid growth of production and its waste byproducts, and this has produced both an acute and chronicproblematic relationship between nature and society.

Crop production, processing, and consumption of its products lead to vast amounts of consumed biomass. Using this organic waste to increase the balance of organic matter in the soil is usually the most acceptable solution, but not in all cases. This is since the direct application of waste enhances the greenhouse effect (Powlson et al., 2008) and often leads to increased soil toxicity, which is caused by both chemical and biological properties of plant material and pesticide residues (Naseer et al., 2014). There are currently several alternative approaches to the disposal of plant residues, particularly for the production of food ingredients (Laufenberg et al., 2003; Baiano, 2014) and the production of biosorbents (Laufenberg et al., 2003). The problems of crop utilization give rise to various aspects of their processing from basic ones, related to residues' origin and physicochemical characteristics (Angulo et al., 2012) to more specialized reasons, based on biotic approaches, including destruction processes. Because of the above, research regarding the study of microorganisms' taxonomic specificity that colonize plant raw materials during its processing has become especially relevant.

Amongst the bacteria involved in the colonization of substrates of plant origin, the most active representatives of Actinobacteria, Bacteroidetes, Firmicutes, Proteobacteria, Spirochaetes, Thermotoga; among the archaea - primarily methyl-forming, belonging to the phylum Euryarchaeota; among the lower fungi
- representatives of the class Zygomycota; among the higher fungi - classes Ascomycota and Basidiomycota (Ryckeboer et al., 2003; Lu et al., 2005; Ros et al., 2013; Pandit et al., 2016; Du \& Li, 2016).

There are some contradictions regarding the species composition of microorganisms involved in the transformation of vegetable residues. In particular, in anaerobic conditions in the destruction of rice straw, vegetable, and food waste, the most significant activity is found in the genus Ruminococcus, and in thermophilic conditions - Thermoanaerobacterium aotearoense (Hernon et al., 2006). In the process of composting a mixture of vegetable waste and the remains of cut flowers, the most numerous species were Bacillus cereus and B. pasteurii (Lu et al., 2005). The Pseudomonas alcaligenes strain was identified during its cooling phase and Brevundimonas diminuta - during the maturation phase (Ryckeboer et al., 2003). Significant differences in the taxonomic composition of microorganisms were also observed depending on the chemical composition of the residues, and particularly: representatives of the genera Pseudomonas, Burkholderia, Pandoraea, Sphingomonas, and Thermotoga were actively involved in the destruction of lignocellulose of rice straw, vegetable and food waste (Sathishkumar et al., 2010; Pandit et al., 2016).

Regarding lower fungi, it is reported that species of the genus Mucor were identified in the process of composting a mixture of vegetable, fruit, and garden waste at different preparatory phases (Ryckeboer et al., 2003). Fisgativa et al. (2017) testify to the active participation of ascomycetes in the transformation of plant waste. Some members of this group of microorganisms are also used in wastewater treatment (Lu et al., 2011). Scientists have focused on the studied species Trichoderma viride, Aspergillus awamori, and A. nidulans to obtain humic acids (Sathishkumar et al., 2010; Motta \& Santana, 2013). In general, micromycetes are powerful biological destructors of various natural origin substances, including glycoside hydrolases, lyases, esterases, and other enzymes. The role of micromycetes in the transformation of cellulose is crucial.

The lack of cost-effective and environmentally safe approaches to the 
A

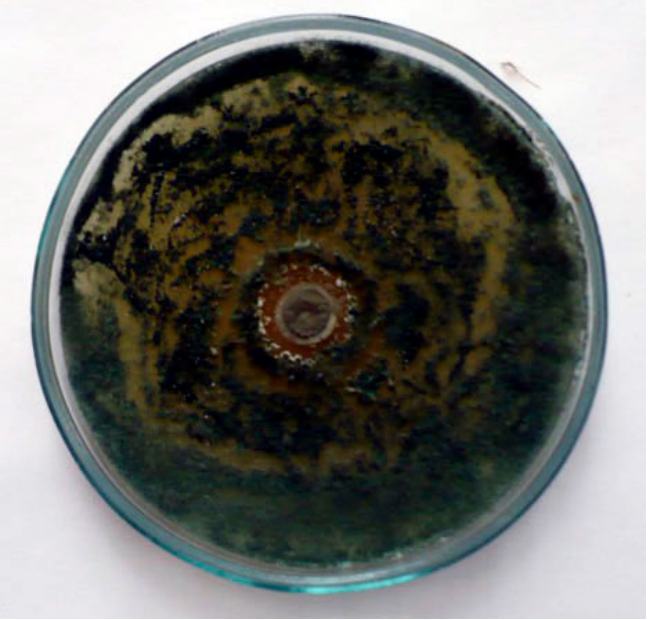

B

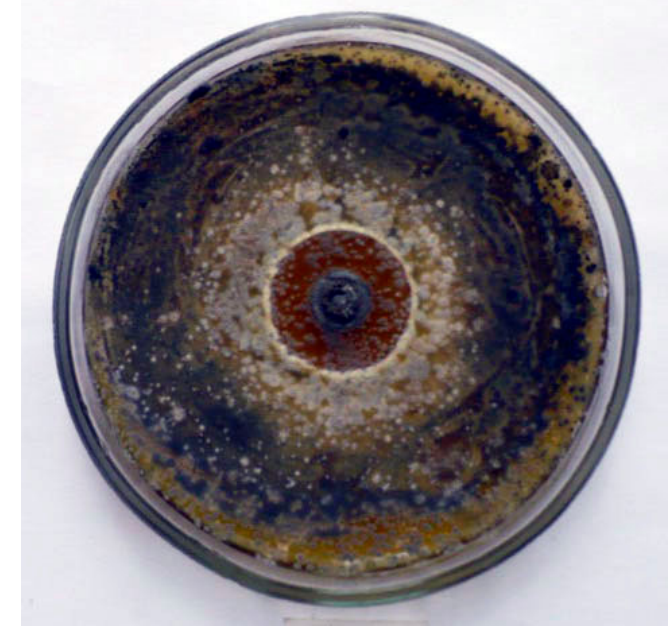

Figure 1. The absence of display antagonistic activity of Penicillium roseopurpureum strains against Trichoderma hamatum (A) and T. koningii (B).

disposal of crop residues leads to the loss of almost $15 \%$ of all agricultural production. Therefore, eliminating the current global environmental crisis associated with vast amounts of waste is one of the most important challenges facing humanity. A solution to the above requires changes in both the environmental strategy and the tactics used in our overall economic model.

Every year agricultural and processing enterprises accumulate a large amount of waste, influenced by various microorganisms (mostly bacteria and micromycetes) that are primarily disposed of during destruction. However, this process is prolonged and uncontrollable. It can be accelerated and controlled by the use of specialized strains of microorganisms which must meet the following criteria: i) high destructive activity against plant material subject disposal; ii) the presence of a high growth rate in the microorganism, which reduces the duration of composting; iii) the absence of evidence of phytopathogenicity. Based on the above, the study aimed to develop a modern, cheap, and environmentally safe technology for the disposal of plant waste, with the participation of the most active microorganismsdestructors.

\section{Material and methods}

We studied the microbiological activity of strains from the collection of the Botanical Garden of the Odesa I.I. Mechnikov
National University to assess the intensity of destruction by industrial plant waste originating from apples, grapes, beets. The micromycete strains of Penicillium roseopurpureum, Trichoderma hamatum, T. koningii, Alternaria alternata, and bacteria of the genus Cytophaga were included in the experimental work. Selected micromycete strains and bacterial cells were cultured on Waxman, and Hutchinson and Clayton (Atlas, 2005) media. To accelerate the rate of microorganism development, we used silicon-containing mineral analcime, which included immobilized spores of micromycetes and bacterial cells' suspensions. Modified analcime was added to the waste in a ratio of $10: 1$. The plant remains prepared in this method were analyzed under conditions of both model and vegetation experiments. During the transformation process, the state of waste was determined after 10,20, and 30 days of constant photofixation.

In the model experiments, corn was used as a test crop. Analcime-enriched vegetable waste in the amount of 100,200 , and $300 \mathrm{mg}$ per $200 \mathrm{~g}$ of the mixture was added to the soil mixture, which included horse manure, humus, sand, and sod soil at a ratio of $1: 1: 1: 1$. Seed germination and development of maize sprouts were evaluated to establish the most integrated indicators according to the experiment's variants. In indoor farming conditions, during the preparation of soil substrates, the application of modified plant waste was $10 \%$ of the mixture's total volume. 

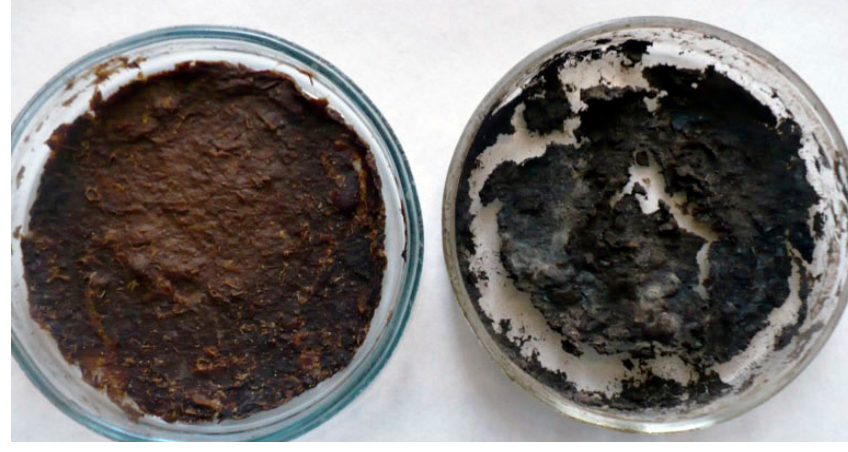

\section{Control}

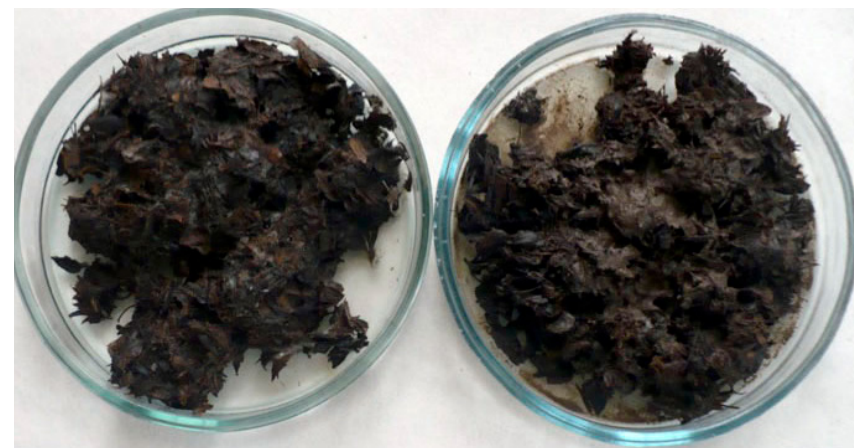

Control

Penicillium roseopurpureum

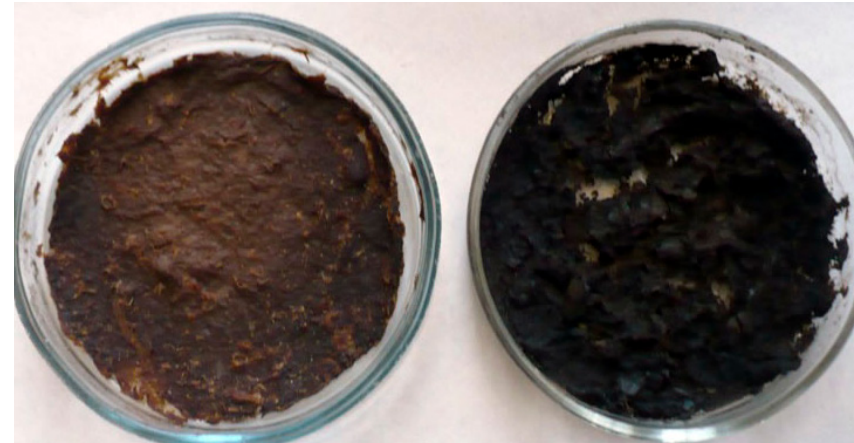

Control

Alternaria alternata

We conducted a comparative analysis of the content of nutrients, phytotoxicity, and biochemical parameters among the selected samples of the soil mixture. Phytotoxicity analysis was performed by direct biotesting. The growth of watercress roots of Lepidium sativum L. was applied as a biotest (Grodzinskij et al., 1990). The content of phenolic compounds was evaluated by the desorption method (Grodzinskij et al., 1988). The redox potential (ORP) was measured in soil suspension modeling soil solution at the soil to distilled water ratio as $1: 1$ by potentiometric technique (Fiedler et al., 2007; Labuda \& Vetchinnikov, 2011). The distribution of macro- and microelements in the soil mixture was determined by Rinkis \& Nollendorf (1982) method on an inductively coupled plasma

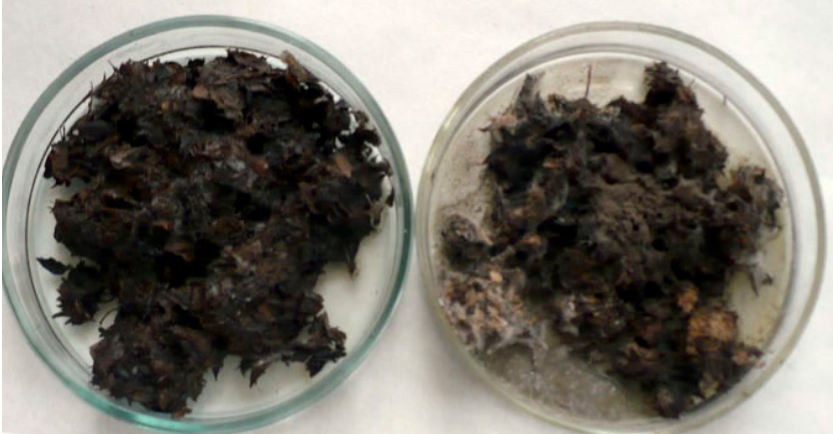

Control

Trichoderma koningii

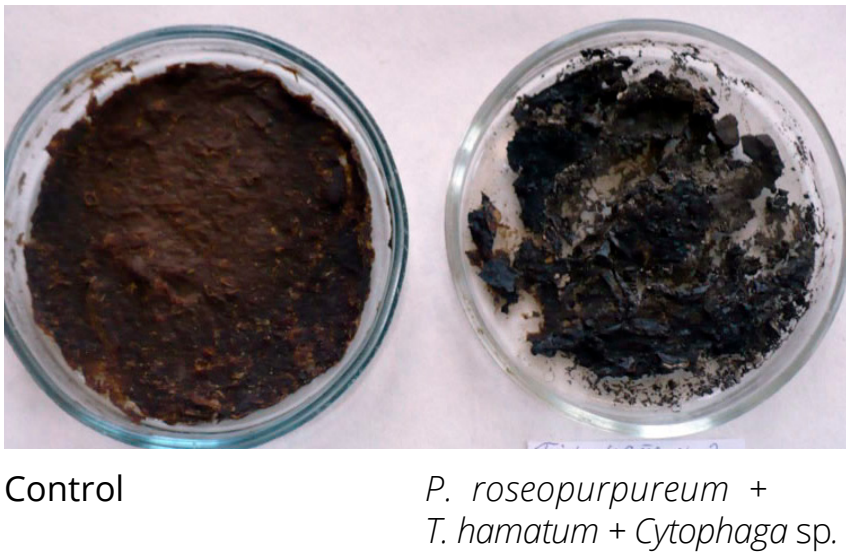

Figure 2. The state of apple waste on the $30^{\text {th }}$ day of the experiment. spectrophotometer iCAP 6300 DUO. The concentrations of $\mathrm{NH}_{4}^{+}$and $\mathrm{NO}_{3}{ }^{-}$were measured spectrophotometrically.

The research results were processed mathematically using the methods of parametric and nonparametric statistics at a 95\% significance level. The groups of values were compared by Mann-Whitney U-criterion. This is the statistical criterion used to assess differences between two independent samples, allows us to identify differences in the parameter value between small samples for $\mathrm{P}<0.05, \mathrm{P}<0.01$, and $\mathrm{P}<0.001$. Quantitative indicators of the content of mineral nutrients in leaves and soil are given as arithmetic mean with standard deviation. 

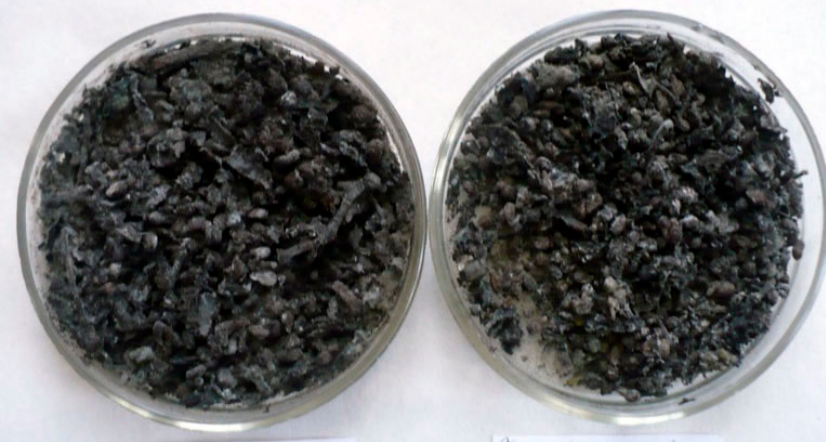

Control

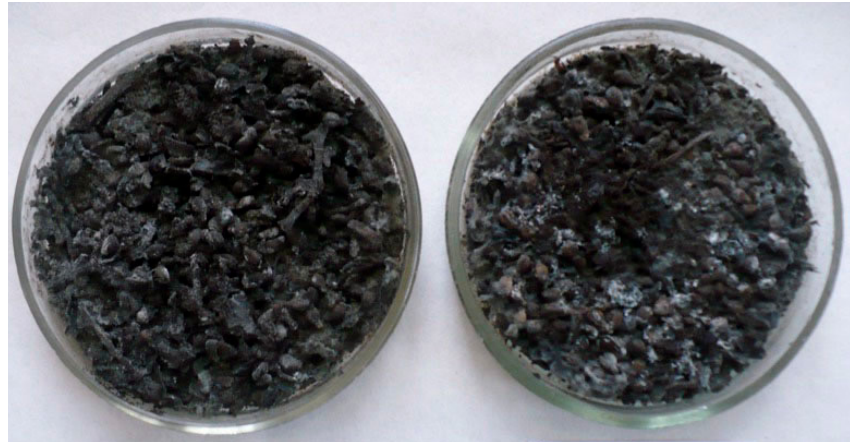

Control

Penicillium roseopurpureum

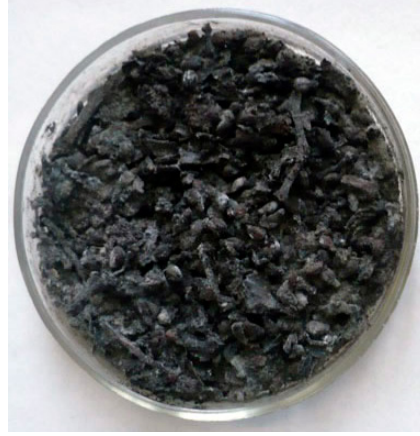

Control

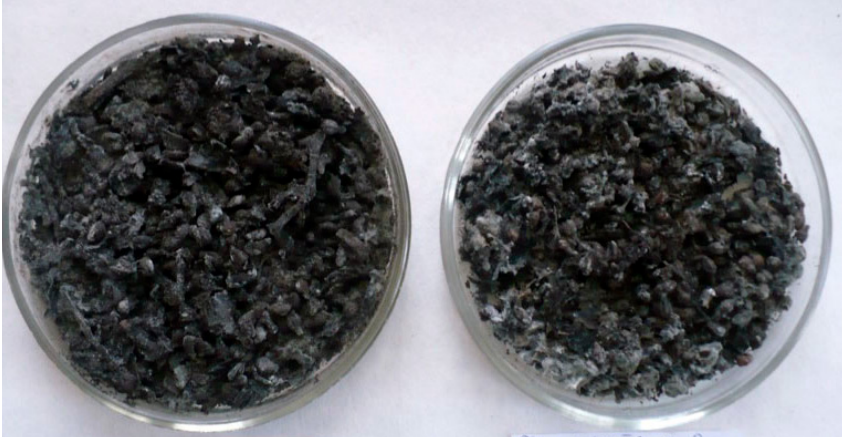

Control

Trichoderma koningii

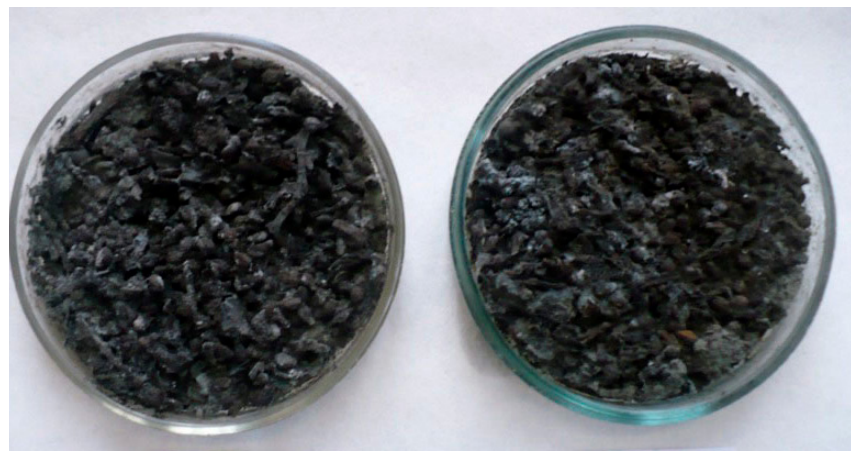

Control

P. roseopurpureum +

T. hamatum + Cytophaga sp.

Figure 3. The state of grape waste on the $30^{\text {th }}$ day of the experiment.

\section{Results and discussion}

At the first stage of our research, we carried out selecting the most effective cultures of microorganisms, or their association, from 2-3 strains suitable for utilization in plant waste. While creating an association of several cultures, it was necessary to determine the relationship between these organisms. Previous studies have shown that the P. roseopurpureum strain secretes secondary metabolites during growth, particularly curvularine (Gavrilov et al., 2013), which is toxic to phytopathogens of the genera Fusarium, Aureobasidium, Botrytis, and others.

This raises the question of elucidating the antagonistic activity of $P$. roseopurpureum against strains of the genus Trichoderma. The results of the conducted experiments showed the absence of antagonistic activity, which is very important because when creating an association, it becomes possible to use a phytopathogenic active strain jointly. The absence of any inhibition of the development of T. hamatum and T. koningii strains in $\mathrm{CO}^{-}$ cultivation with $\mathrm{P}$. roseopurpureum is shown on the Fig. 1.

At the next stage of our experimental work, the silicon-containing mineral analcime was used as a starting material for immobilization of spores and suspension of bacterial cells of the culture fluid to intensify the growth rate of microorganisms. Based on the results obtained from determining the concentration of microorganisms per $1 \mathrm{~g}$ of analcime, the following dependence was obtained, CFU (colony-forming units): P. roseopurpureum $-1.8 \cdot 10^{6} ;$ T. hamatum $-2.5 \cdot 10^{5} ;$ T. koningii - 

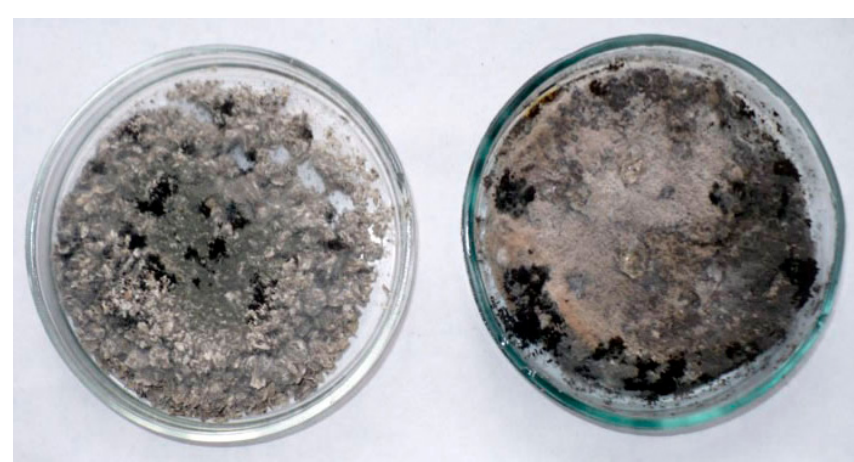

Control

Trichoderma hamatum

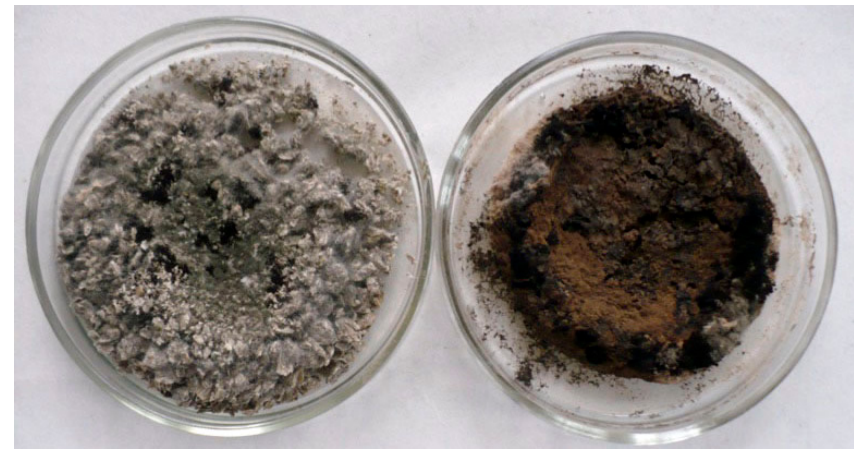

\section{Control}

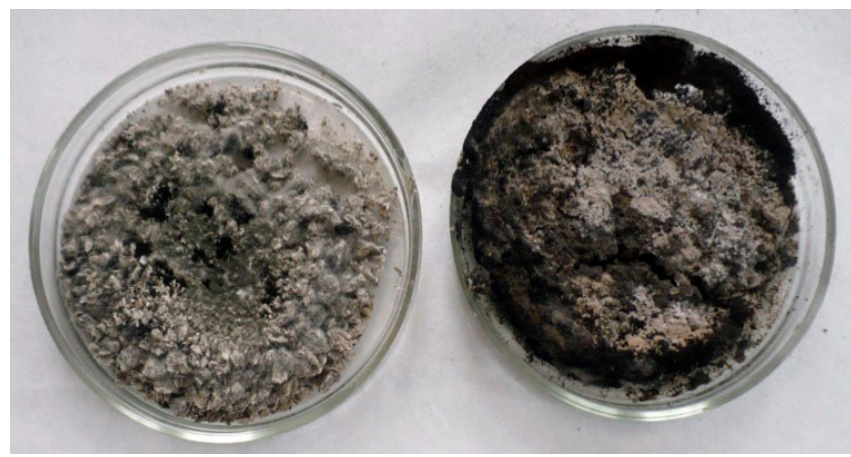

Control

Alternaria alternata

$2.5 \cdot 10^{5} ;$ A. alternata $-1.7 \cdot 10^{3} ;$ Cytophaga sp. $-1.1 \cdot 10^{5}$.

Using this methodology, analcime was enriched and mixed with industrial waste from apples, grapes, and beets in a ratio of 1:10. The destructive activity of microorganisms was assessed for one month, every ten days, using photofixation. The photos clearly show that during this period, both the volume and weight of the studied waste significantly decreased (Figs. 2-4).

According to the change in qualitative indicators after the destruction of plant remains, the quantitative characteristics have also changed (Figs. 5-7). Charts of the dynamic changes in waste disposal through appropriate microorganisms show that this process is more intensive in the beet waste.

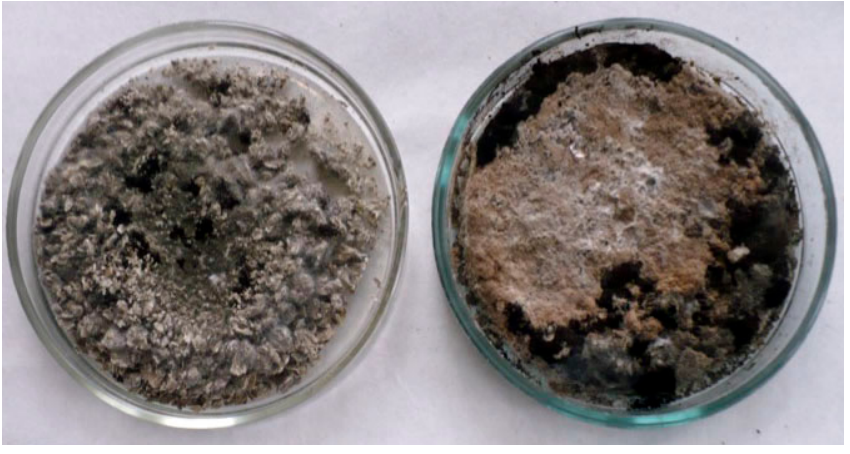

Control Trichoderma koningii

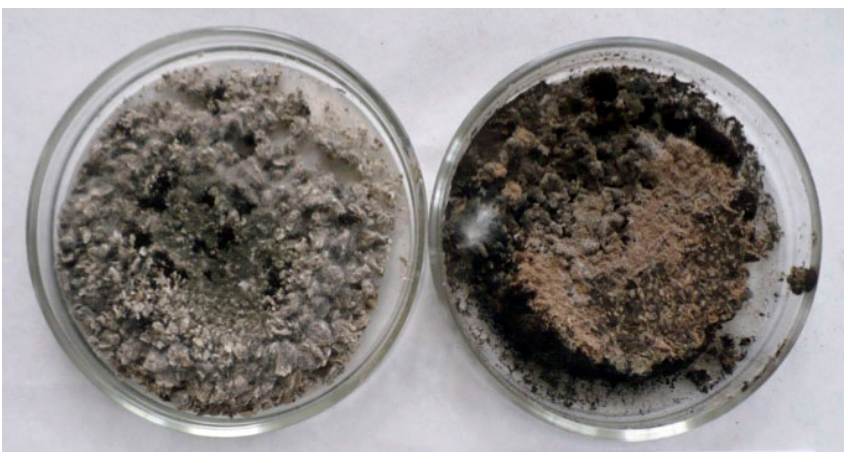

Control

P. roseopurpureum +

T. hamatum + Cytophaga sp.

Figure 4 . The state of beet waste on the $30^{\text {th }}$ day of the experiment. 


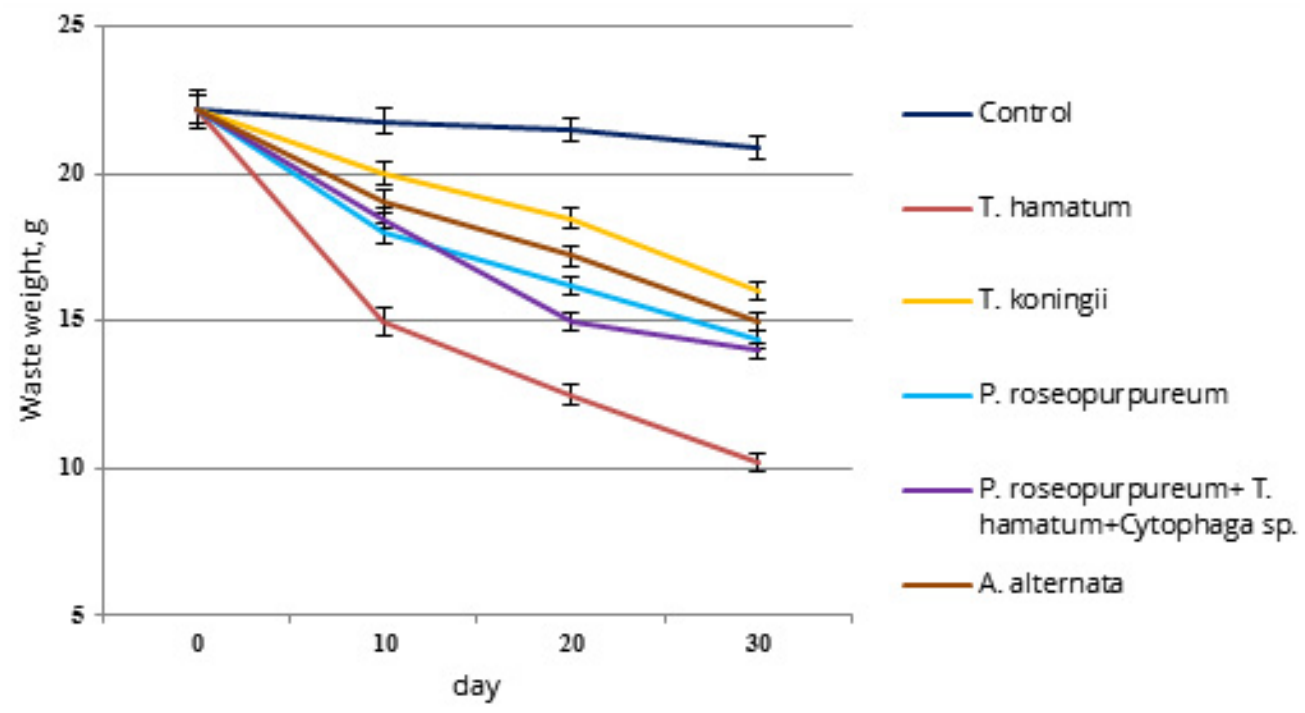

Figure 5. The dynamics of apple waste transformation under the influence of microorganisms.

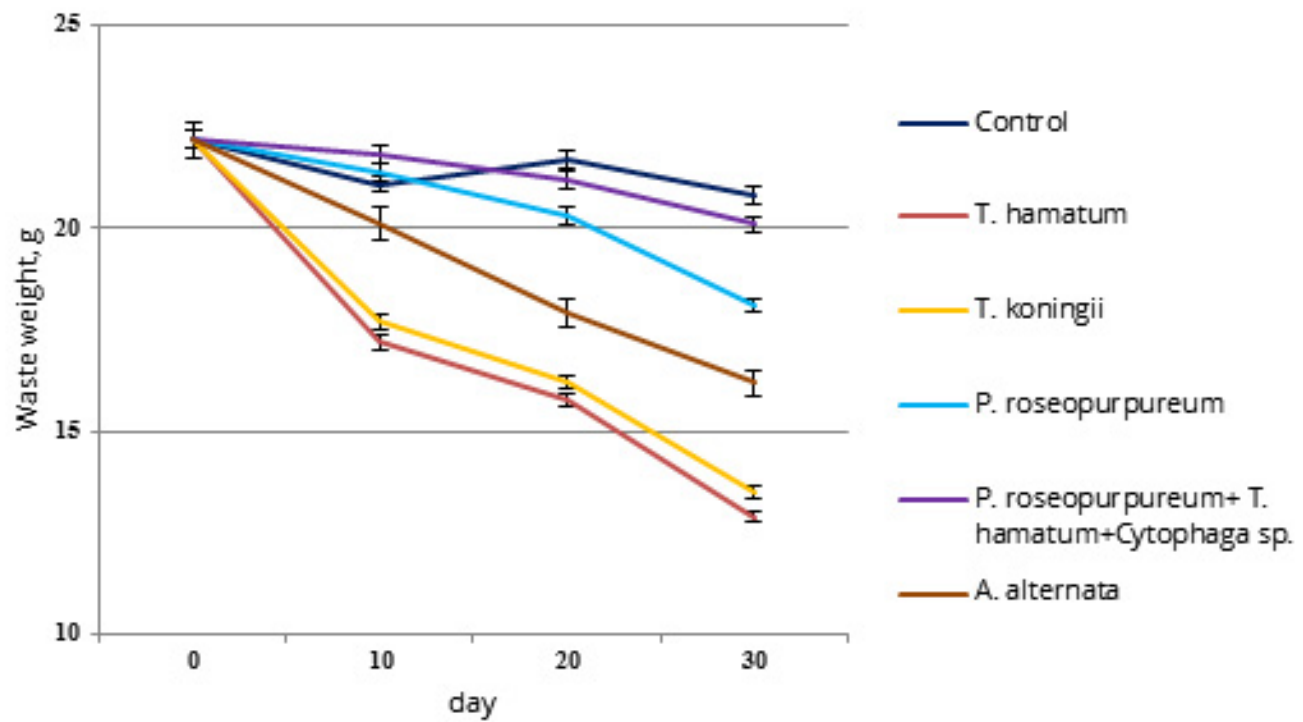

Figure 6. The dynamics of grape waste transformation under the influence of microorganisms.

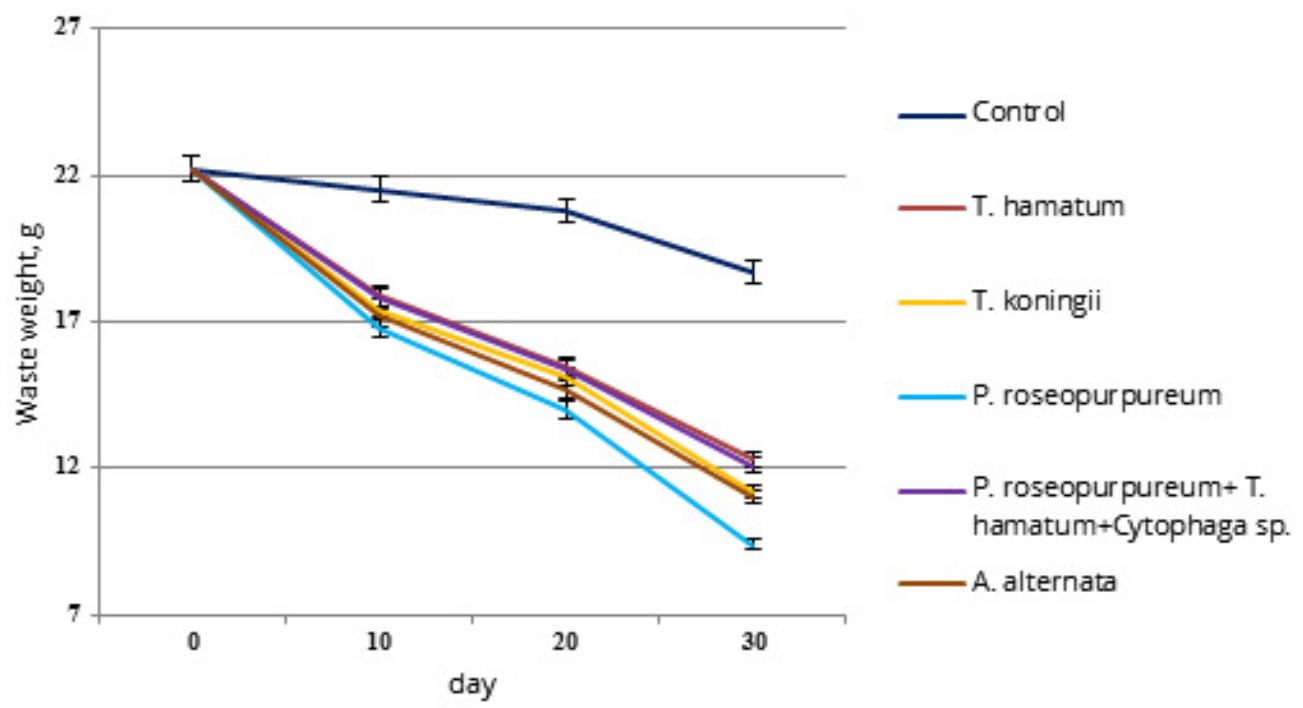

Figure 7. The dynamics of beet waste transformation under the influence of microorganisms. 
Table 1. The destructive activity of microorganisms during 30 days while using them for waste disposal according to weight criteria, \% to control.

\begin{tabular}{llll}
\hline \multirow{2}{*}{ Strains of microorganisms } & \multicolumn{3}{c}{ Waste } \\
\cline { 2 - 4 } & Apple & Grape & Beet \\
\hline Control & 100.00 & 100.00 & 100.00 \\
Trichoderma hamatum & 53.82 & 41.53 & 44.60 \\
Trichoderma koningii & 28.10 & 39.09 & 48.90 \\
Penicillium roseopurpureum & 35.27 & 18.50 & 57.50 \\
P. roseopurpureum + T. hamatum + Cytophaga sp. & 36.60 & 9.10 & 45.20 \\
Alternaria alternata & 32.57 & 27.40 & 49.90 \\
\hline
\end{tabular}

At the next stage of the study, waste enriched with analcime was analyzed to determine the most optimal options that would positively affect plant development (Figs. 8-13).

During experiments with microbiological fermentation of plant mass, we noticed that different waste is marked by the species specificity of microorganisms that colonize them, characterized by a stimulating effect on plant development. Species selectivity of microorganisms influencing plant growth processes was revealed for the first time. The greatest stimulation of maize development was observed in the variants with apple waste in the presence of the micromycete T. koningii during application in the amount of $200 \mathrm{mg}$ per $200 \mathrm{~g}$ of the substrate (Figs. 8 \& 9). Slightly worse results were obtained in variants with the strain T. hamatum. A similar pattern was also observed regarding grape waste (Figs. 10 \& 11). The maximum increase of maize was recorded in variants with the strains of T. hamatum. The second most positive option using grape waste was with application of P. roseopurpureum. Regarding beet waste, the best option was with the association of strains of microorganisms (Figs. 12 \& 13).

A similar dependence was obtained for ornamental plants of both closed and open ground, particularly thuja, asparagus, and muraya (Fig. 14). The application of plant waste inoculated with microorganisms in the soil substrate in the amount of $10 \%$ of the mixture's total volume contributed to the activation of growth processes of experimental plant species on average 1.5-2.3 times.

Discovered patterns regarding the species specificity of microorganisms involved in the destruction of plant waste can be associated with the active interaction of microorganisms and higher plants through the synthesis of hormones. However, it should be noted that phytohormones accumulate in plants in excess due to the existence of feedback mechanisms that limit their synthesis. In the culture of microorganisms, phytohormones that are synthesized, in contrast to plants, remain in free form and undergo active transformations. Perhaps the stimulating effects of plant waste inoculated with certain microorganisms on plant development are due to the microbiota's intensive synthesis of hormones. However, this assumption needs further study in detail. The dependence that we have established may also be related to the specific content of macroand microelements in plant waste. Therefore, the next stage of our work was to study the content of nutrients in fruit and vegetable waste.

The study of nutrient ecology is of great importance now, as it is known that in different soils, mineral compounds are almost never contained in such quantities and in such a balanced ratio that would be optimal for plant growth and development (El-Ramady et al., 2014). The latter always compensate for stress factors due to nutrition and subsequent physiological adaptation changes to environmental conditions (Alshaal et al., 2017; Hasanuzzaman et al., 2017; Naeem et al., 2017). Soils, in turn, are characterized by different content of nutrients that determine the certain chemical composition of plants (El-Ramady et al., 2014).

Analysis of the nutrient content in samples of various plant wastes showed a high potassium concentration (Table 2). 


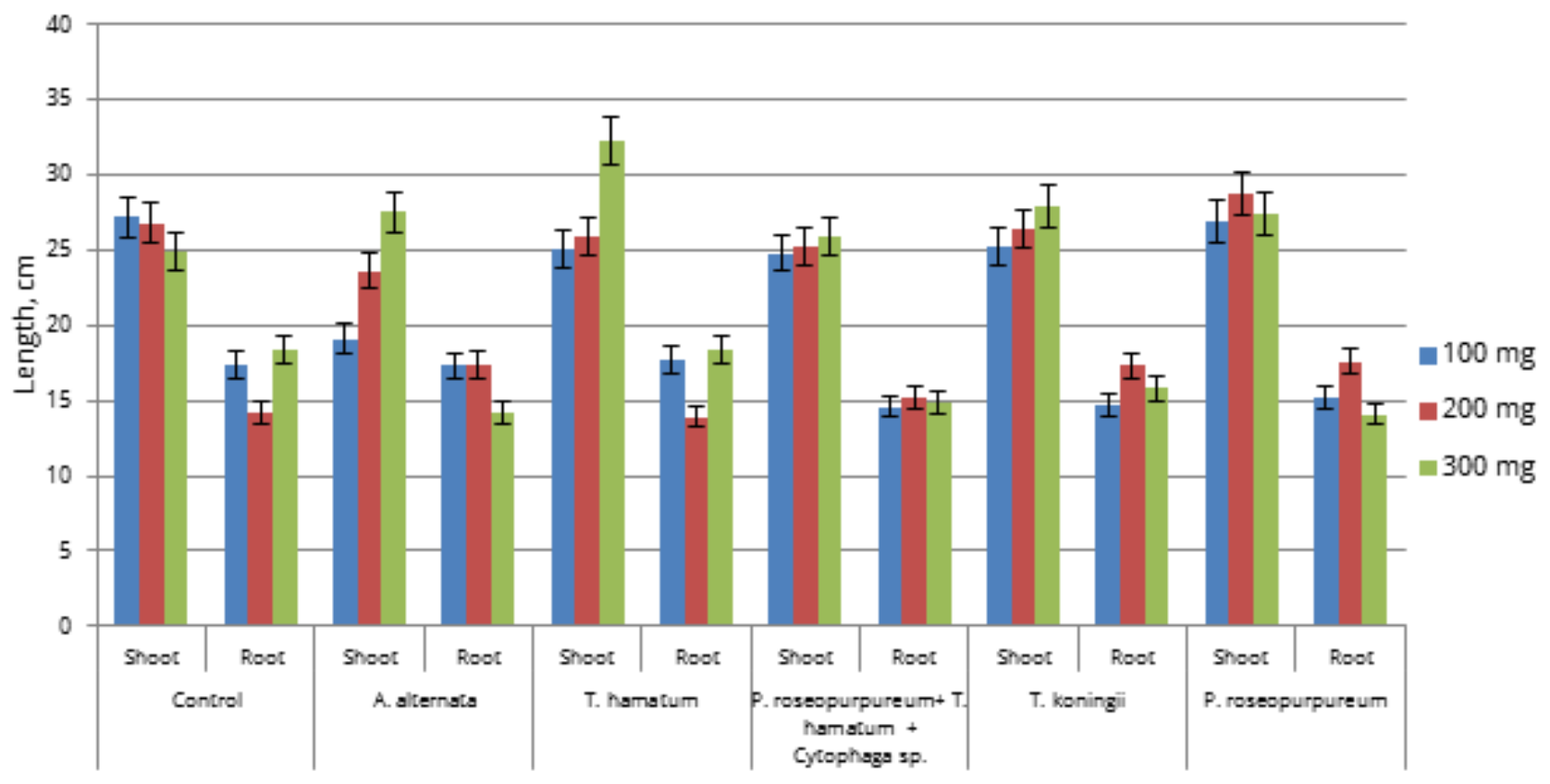

Figure 8. The influence of modified apple waste on growth processes of corn shoots, $\mathrm{cm}$.

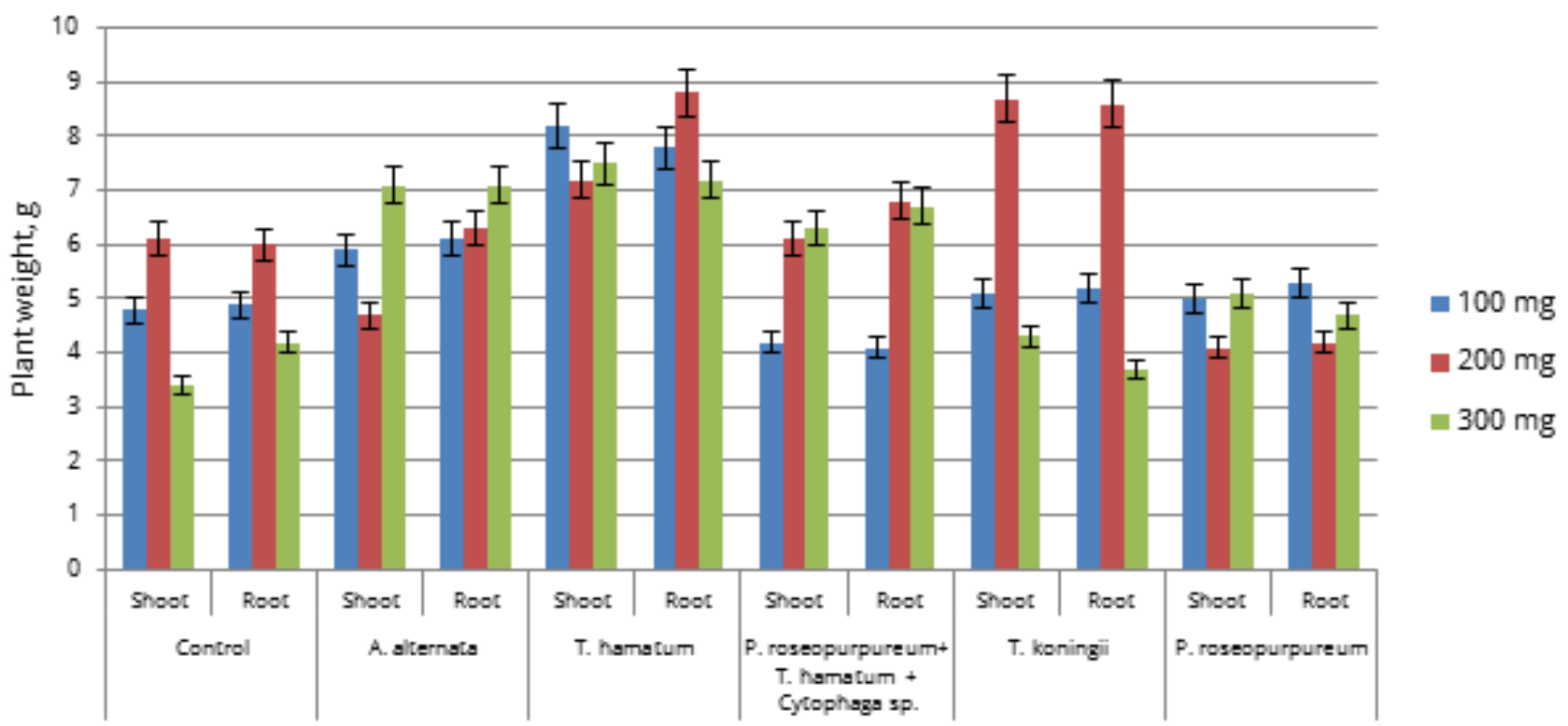

Figure 9. The influence of modified apple waste on biomass accumulation by corn shoots, $\mathrm{g}$.

Taking this into account, there is a question regarding the determination of this element in the aqueous extract and the measurement of its electrical conductivity to determine the total content of soluble salts. The study showed that the waste of potatoes and beets are characterized by a high concentration of potassium and can be a basis for creating a mixture that will provide high resistance to drought (Table 3).

In turn, grape waste should be used to stimulate photosynthesis due to its high iron content, while pear and zucchini waste are acceptable for stimulating plants' growth processes due to high nitrogen concentration. All other waste can serve as a basis for developing mixtures to improve the agrophysical and biological state of the soil ecosystem (Table 2).

Our comparative analysis of the macro- and microelements content in the soil substrate after three months of growing ornamental plants revealed significant differences in their distribution depending on the original 


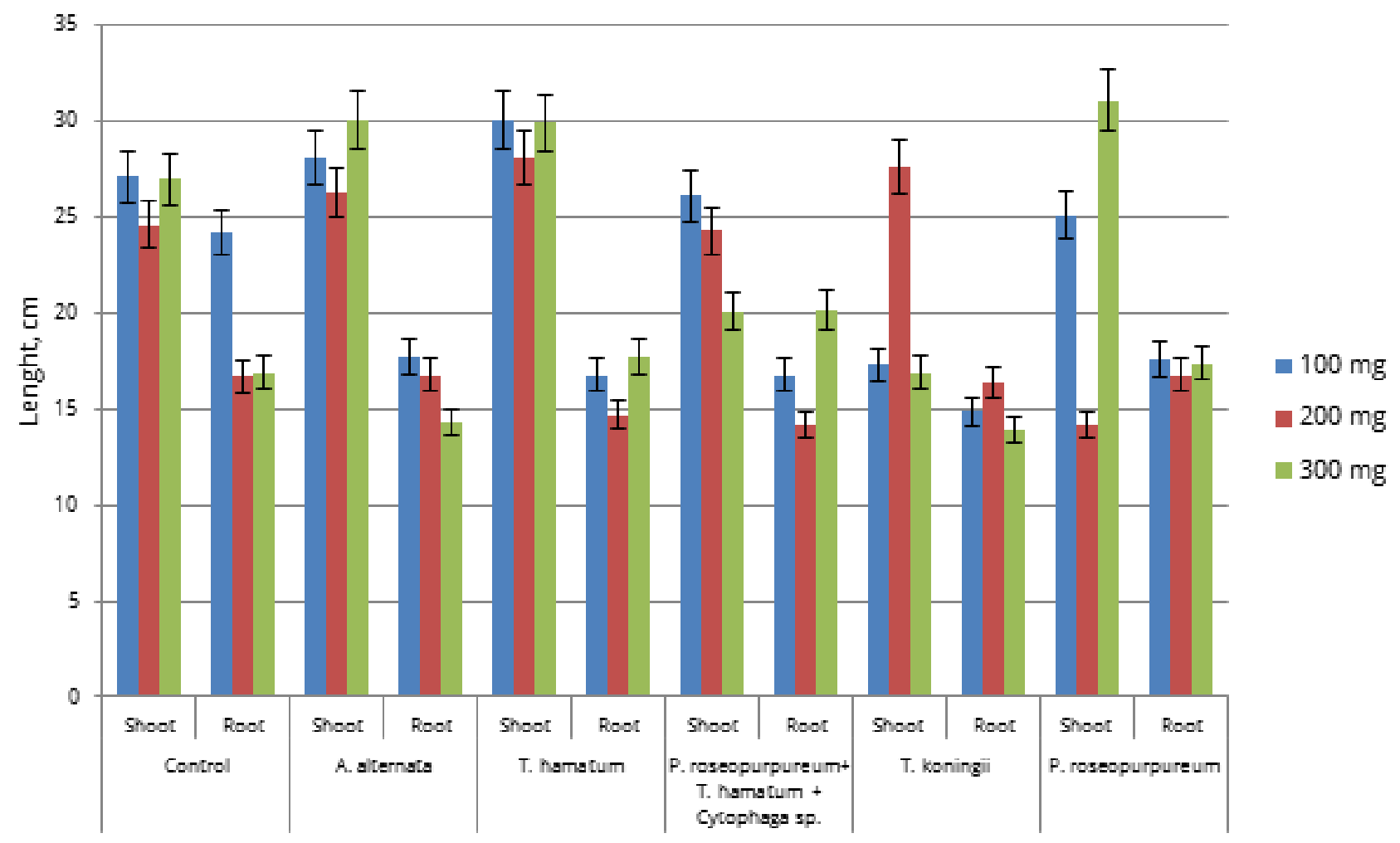

Figure 10. The influence of modified grape waste on growth processes of corn shoots, $\mathrm{cm}$.

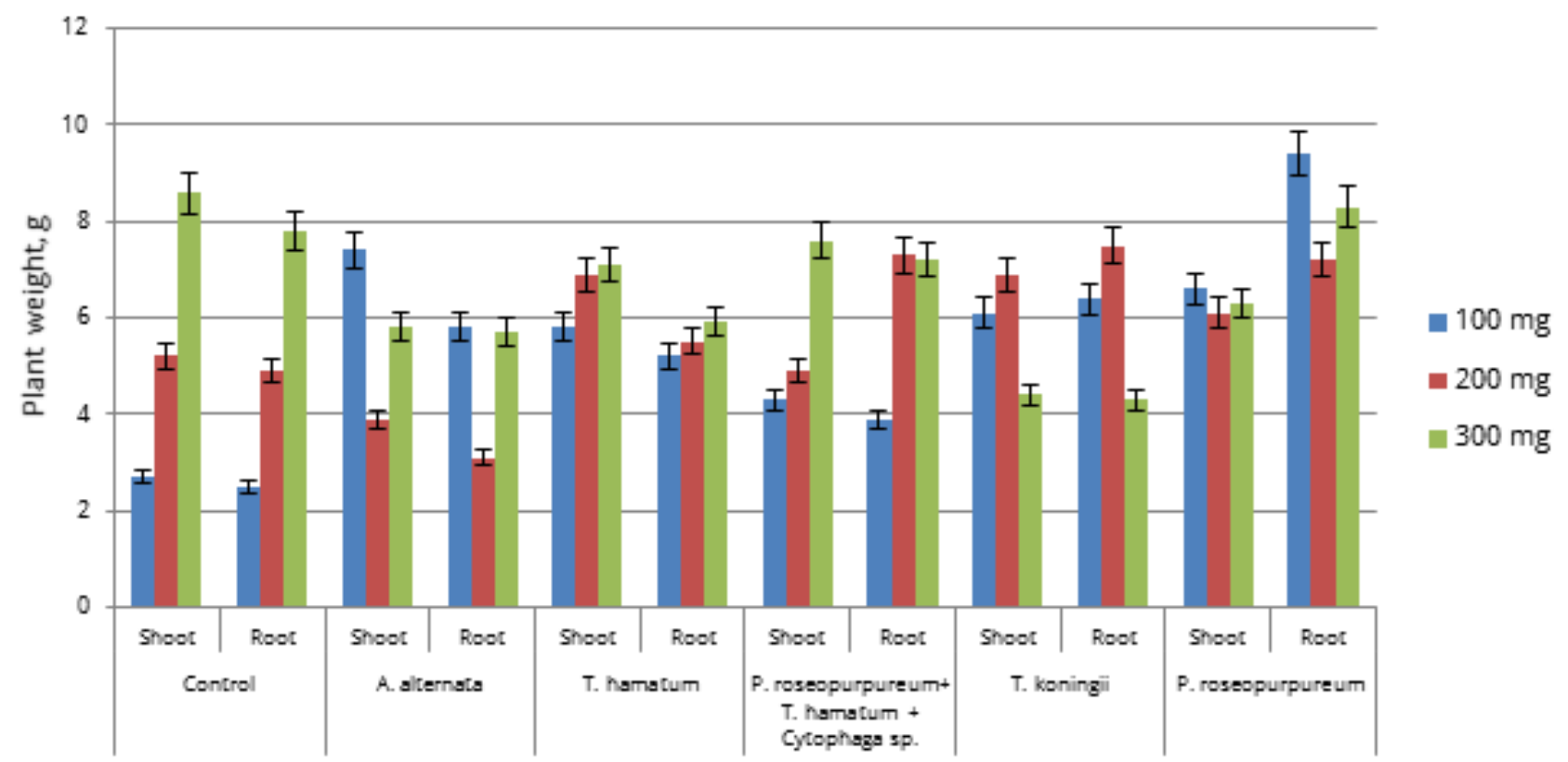

Figure 11. The influence of modified grape waste on biomass accumulation by corn shoots, g.

plant raw materials and species composition of microorganisms. Thus, a new finding from our study was that the application of apple waste to our soil substrates, inoculated with the strain of $\mathrm{T}$. koningii was characterized by a significantly higher concentration of magnesium compared to other variants of the experiment (Fig. 15).
A similar pattern was observed regarding beet waste options, in particular, the increase in magnesium content in the soil substrate with the application of waste inoculated with a mixture of micromycetes and bacteria. Examination of grape waste showed that T. hamatum contributes to the accumulation of calcium in the soil. 


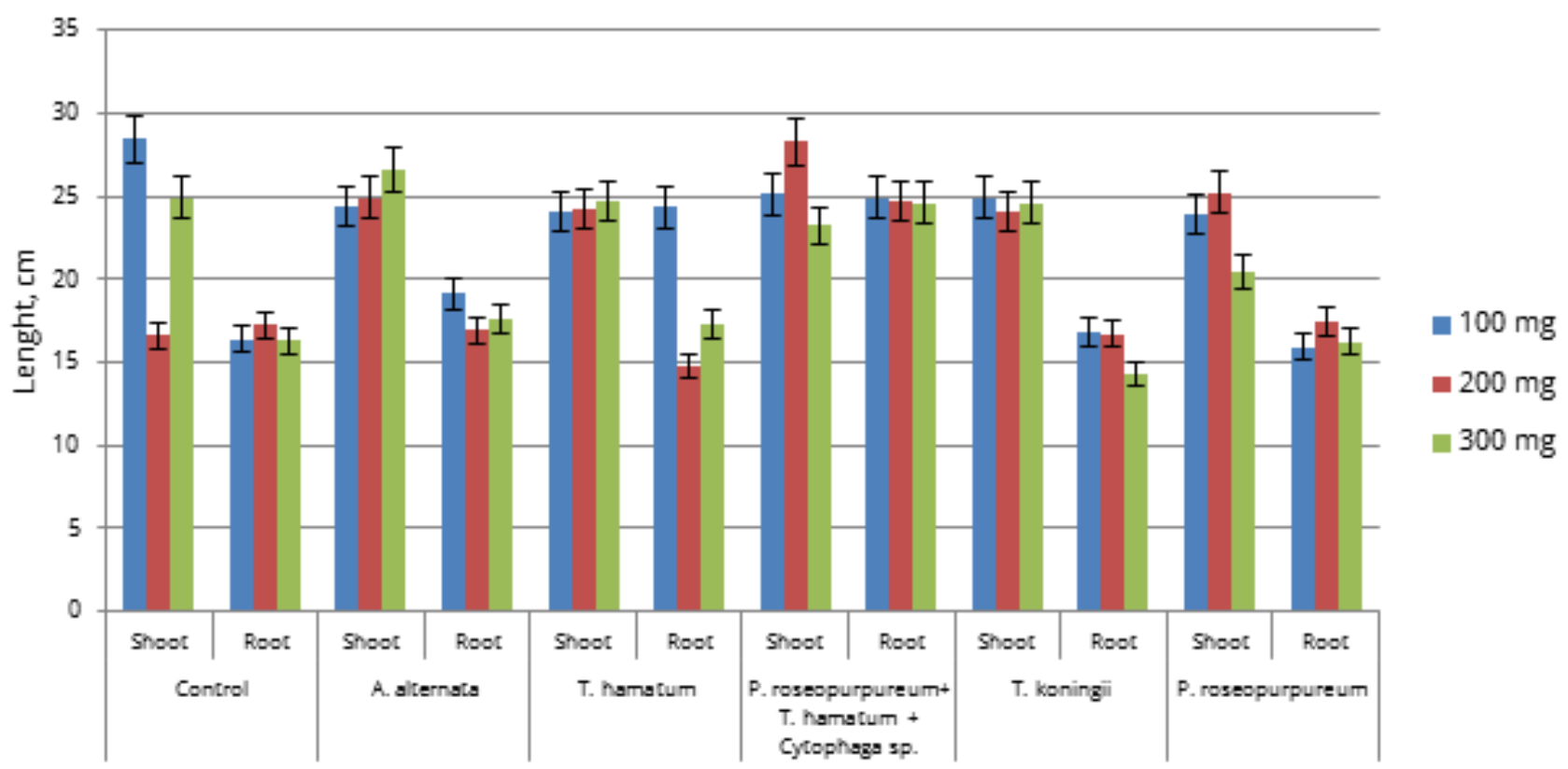

Figure 12. The influence of modified beet waste on growth processes of corn shoots, $\mathrm{cm}$.

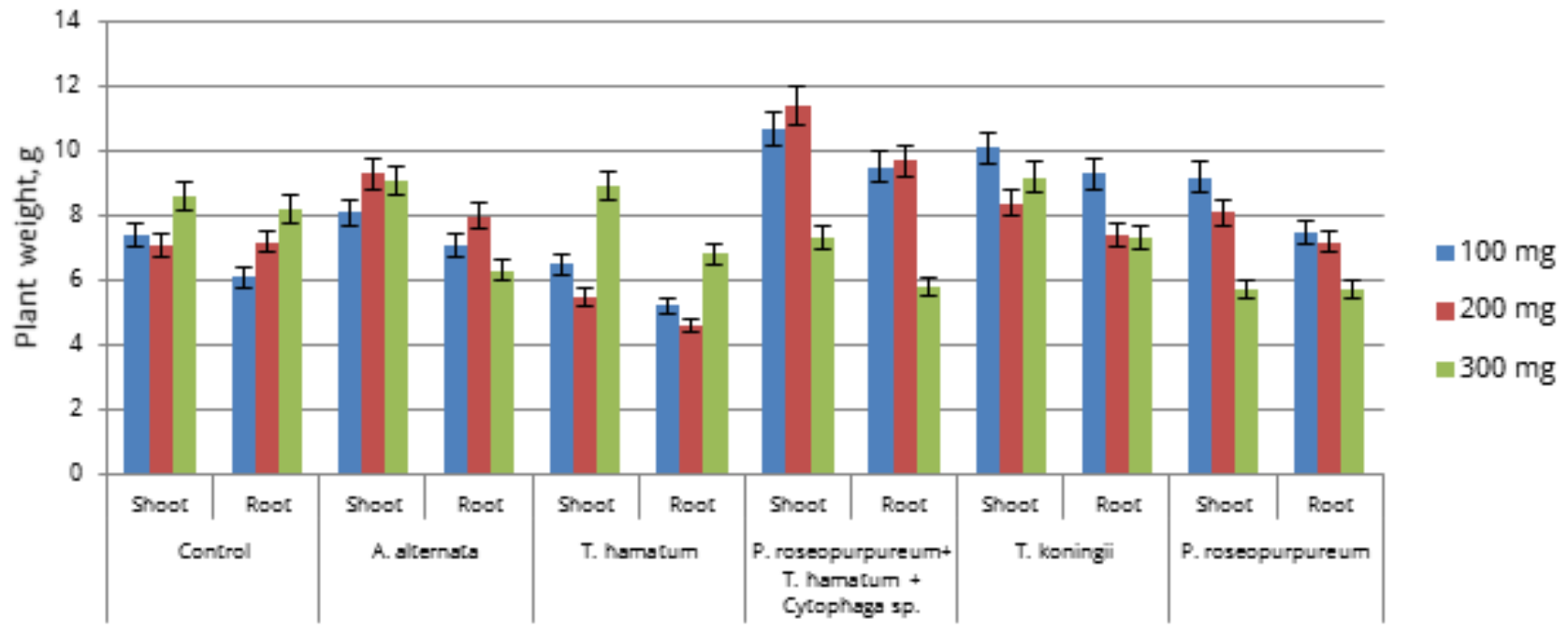

Figure 13. The influence of modified beet waste on biomass accumulation by corn shoots, $g$.

It is noteworthy that ammonia and nitrate nitrogen in the soil substrate in the variants with grape waste inoculated by spores of P. roseopurpureum increased (Fig. 16).

The decrease in the concentration of all other nutrients in the soil, especially manganese, of the experimental variants indicates the intensive absorption of nutrients by the experimental plants, which positively affected their development. In turn, a decrease in manganese content indicates a decrease in its phytotoxicity (Figs. 17 \& 18).

The optimization of redox processes in the soil with the application of plant residues is evidenced by the indicators of ORP. The evaluation of the soil's biochemical state (ORP values, being closely related to the conversion of organic matter) helped us understand that the variants with plant waste inoculated with microorganisms had significantly higher ORP values than the control (Fig. 19).

Meanwhile, the nature of the redox process in the control variants has more intense reduction reactions, unlike the experiment's variants. Reducing the activity of reduction processes and increasing the oxidation processes in the substrate with the application of plant waste inoculated with microorganisms positively affect the nutrient regime and soil fertility (Fig. 20). The obtained 
Table 2. The content of nutrients $(1 \mathrm{M} \mathrm{HCl})$ in plant waste, $\mathrm{mg} / \mathrm{l}$.

\begin{tabular}{llllllllll}
\hline Elements & $\mathrm{NH}_{4}^{+}$ & $\mathrm{NO}_{3}{ }^{-}$ & $\mathrm{P}$ & $\mathrm{K}$ & $\mathrm{Ca}$ & $\mathrm{Mg}$ & $\mathrm{Fe}$ & $\mathrm{S}$ & $\mathrm{Mn}$ \\
\hline Orange & 142.3 & 0.9 & 82.0 & 3273.3 & 1166.2 & 508.0 & 125.0 & 99.7 & 4.2 \\
Onion & 100.8 & 4.7 & 109.3 & 1660.0 & 999.6 & 508.0 & 2.8 & 61.4 & 4.7 \\
Carrot & 352.1 & 4.2 & 56.1 & 2164.2 & 1166.2 & 304.8 & 11.1 & 375.2 & 49.8 \\
Cabbage & 106.4 & 3.9 & 111.3 & 2257.2 & 4331.6 & 203.2 & 0.7 & 224.8 & 4.1 \\
Beet & 164.3 & 0.8 & 108.6 & 4291.2 & 5164.6 & 711.2 & 0.9 & 502.3 & 3.9 \\
Potato & 142.5 & 1.1 & 112.5 & 3031.5 & 8829.8 & 609.6 & 0.5 & 397.5 & 32.1 \\
Red tomato & 159.7 & 0.7 & 107.3 & 2529.0 & 999.6 & 304.8 & 1.1 & 126.1 & 39.8 \\
Pink tomato & 121.3 & 1.8 & 55.2 & 2529.0 & 999.6 & 304.8 & 1.9 & 122.7 & 51.3 \\
Zucchini & 84.5 & 5.7 & 105.8 & 2490.3 & 666.4 & 406.4 & 0.4 & 87.5 & 62.7 \\
Cucumber & 99.6 & 0.9 & 273.5 & 2630.7 & 999.6 & 21.9 & 0.3 & 225.0 & 91.8 \\
Pumpkin & 32.8 & 1.3 & 83.6 & 2406.6 & 999.6 & 609.6 & 0.7 & 129.4 & 4.2 \\
Pear & 356.4 & 1.4 & 56.1 & 1371.6 & 1332.8 & 711.2 & 0.5 & 63.4 & 99.4 \\
Apple & 211.5 & 3.6 & 83.2 & 1818.9 & 2499.0 & 1219.2 & 0.1 & 452.7 & 58.3 \\
Grape & 214.3 & 7.5 & 81.9 & 2182.5 & 999.6 & 101.6 & 251.6 & 149.3 & 0.9 \\
\hline
\end{tabular}

Note. $n=5, P<0.05$.

Table 3. Potassium content $(\mathrm{mg} / \mathrm{l})$ and electrical conductivity $(\mathrm{mSm})$ of the aqueous solution of plant waste.

\begin{tabular}{lll}
\hline Waste & $\mathrm{K}, \mathrm{mg} / \mathrm{l}$ & $\mathrm{EC}, \mathrm{mSm} / \mathrm{cm}$ \\
\hline Orange & 552.7 & 1.7 \\
Onion & 472.2 & 1.5 \\
Carrot & 544.1 & 3.4 \\
Cabbage & 592.0 & 2.1 \\
Beet & 1044.5 & 4.2 \\
Potato & 1032.9 & 3.4 \\
Red tomato & 576.4 & 2.1 \\
Pink tomato & 632.3 & 1.9 \\
Zucchini & 608.2 & 2.1 \\
Cucumber & 624.8 & 2.4 \\
Pumpkin & 568.7 & 1.9 \\
Pear & 432.5 & 1.2 \\
Apple & 448.0 & 1.3 \\
Grape & 636.9 & 1.8 \\
\hline
\end{tabular}

Note. $n=5, P<0.05$. dependence indicates a decrease in the level of mobile organic matter in the soil and its rapid transformation into stable forms with subsequent humus formation.

Among non-specific organic compounds, phenols occupy an essential place, the physiological role of which depends on their accumulation in the soil (Pospisil et al., 1981). The high concentrations of mobile phenolic compounds can disrupt plant nutrition and, ultimately, reduce its productivity. Phenols are precursors of humic substances and can, at the same time at certain stages of their transformations, perform an allelopathic function, i.e., cause soil fatigue, inhibit plant growth and development as well as affect the rate of ion absorption (Blum, 2004; Li et al., 2010). The level of labile phenolic compounds in the soil is determined by the rate of release from plant residues, involvement in the synthesis of high molecular weight humic substances, and the production of certain groups of microorganisms (Blum, 2004; Li et al., 2010). Phenolic compounds, primarily phenolic acids, are formed due to enzymatic hydrolysis of lignin by soil microorganisms, and determine the degree of humification ( $\mathrm{Li}$ et al., 2010).

In connection with the above mentioned, the content of phenolic compounds in the soil 

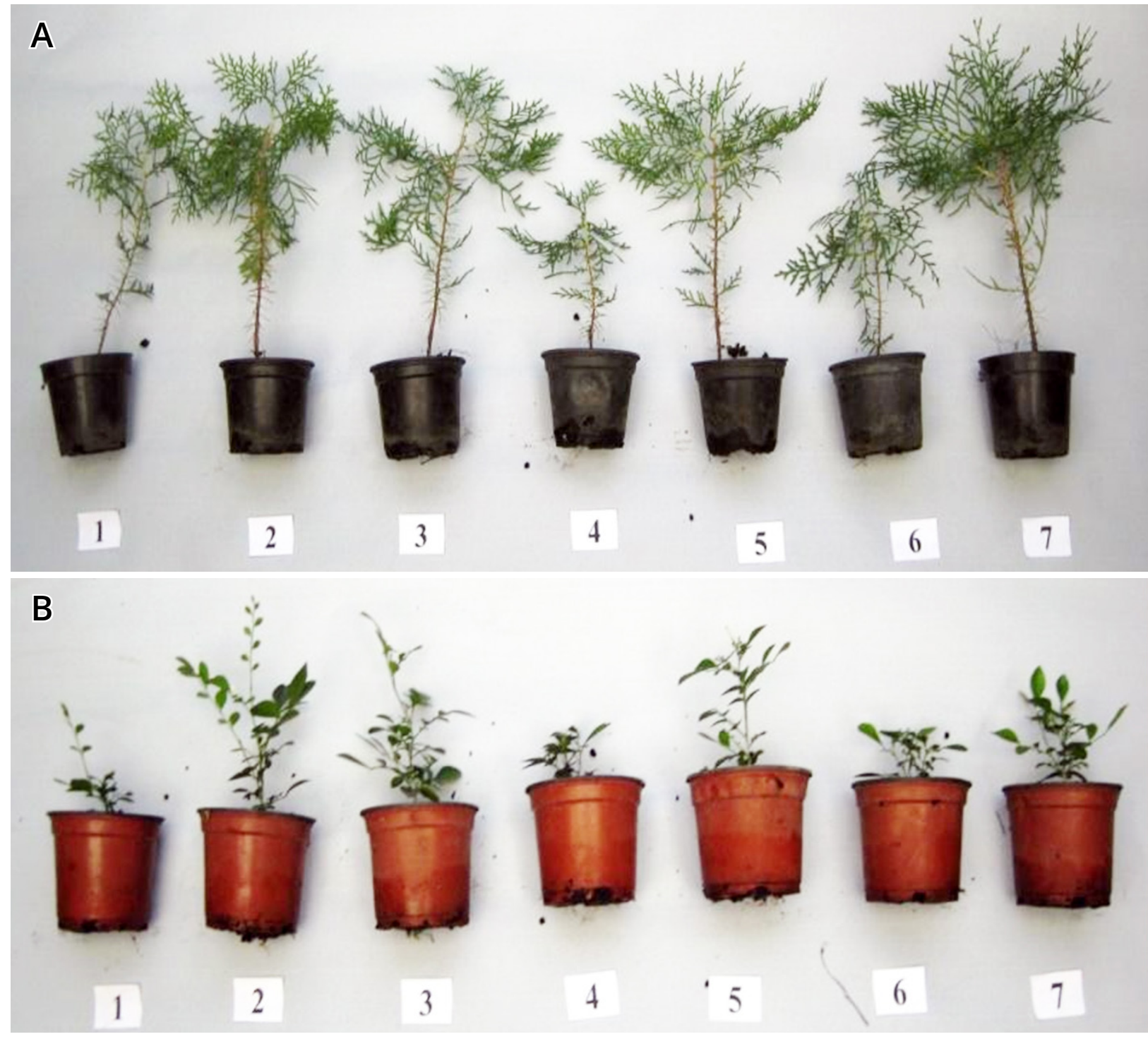

C
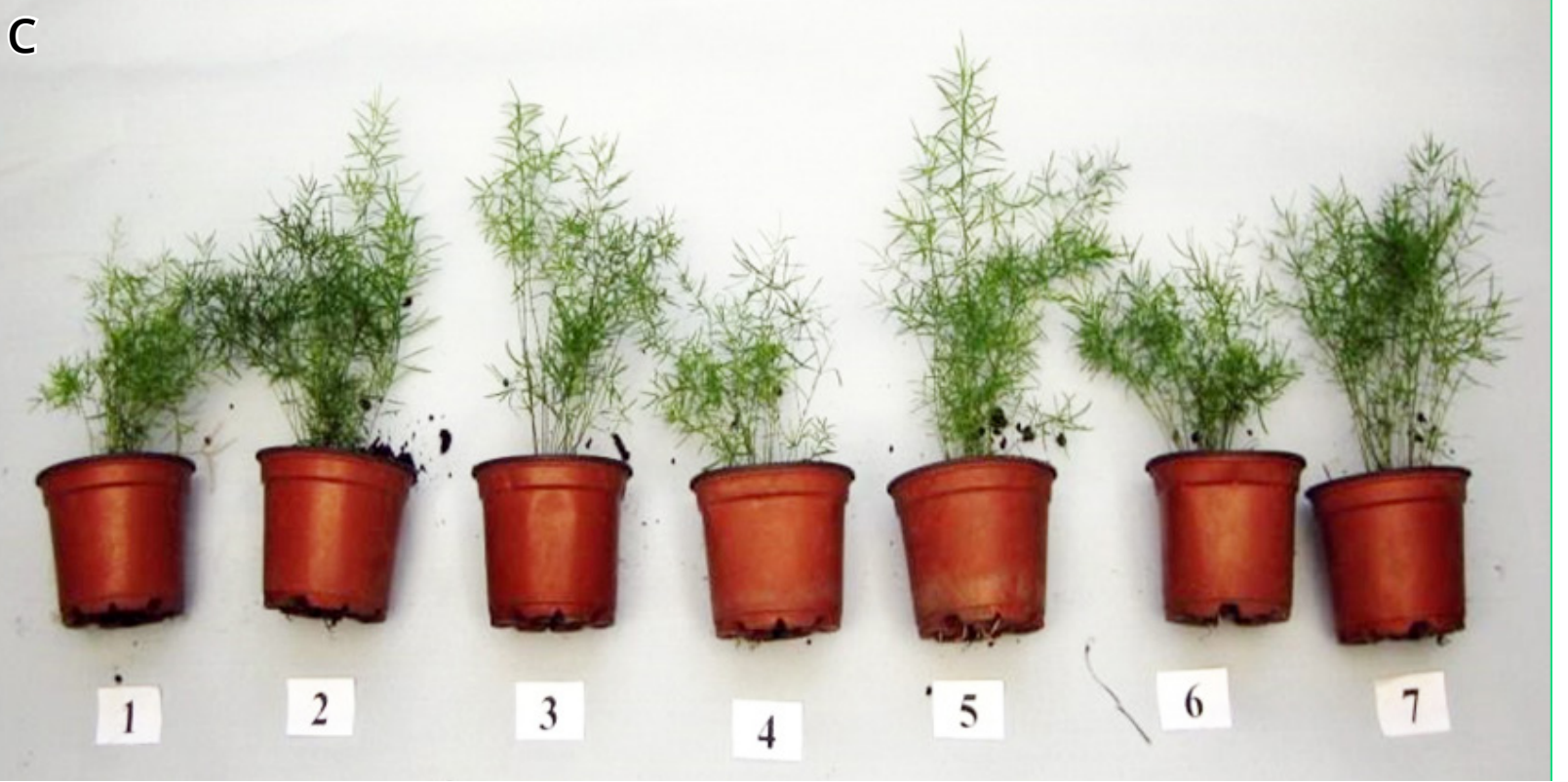

Figure 14. Condition of thuja (A), muraya (B), and asparagus (C) plants after the introduction of plant waste inoculated with microorganisms into the soil substrate. Apple waste: 1 - control, 2 - Trichoderma koningii (dry waste), 3 - T. koningii (wet waste). Grape waste: 4 - control, 5 - T. hamatum. Beet waste: $\mathbf{6}$ - control, 7 - mixture of Penicillium roseopurpureum + T. hamatum + Cytophaga sp. 


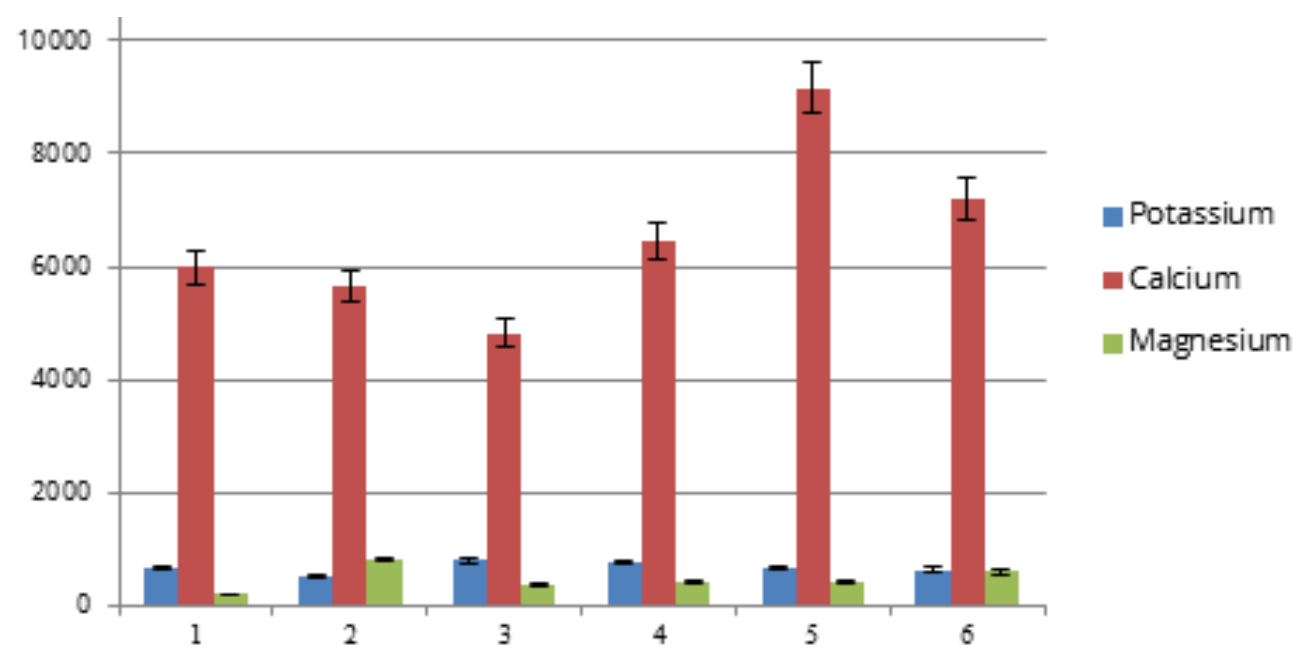

Figure 15. The content of nutrients in the soil substrate when plant waste inoculated with microorganisms, $\mathrm{mg} / \mathrm{l}$ of soil is applied. Apple waste: 1 - control, 2 - Trichoderma koningii. Grape waste: 3 - control, 4 - T. hamatum. Beet waste: 5 - control, 6 - a mixture of Penicillium roseopurpureum + T. hamatum + Cytophaga sp.

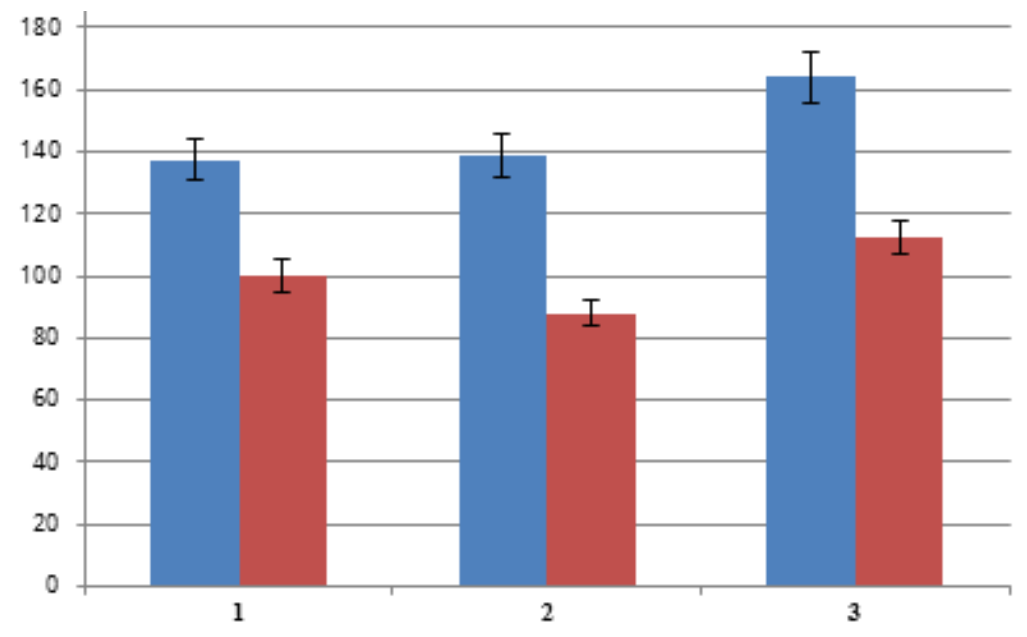

- Ammonia nitrogen

- Nitrate nitr ogen

Figure 16. Nitrogen content in the soil substrate when grape waste inoculated with spores of micromycetes, mg/l of soil is applied: 1 - control, 2 - Trichoderma hamatum, 3 - Penicillium roseopurpureum.

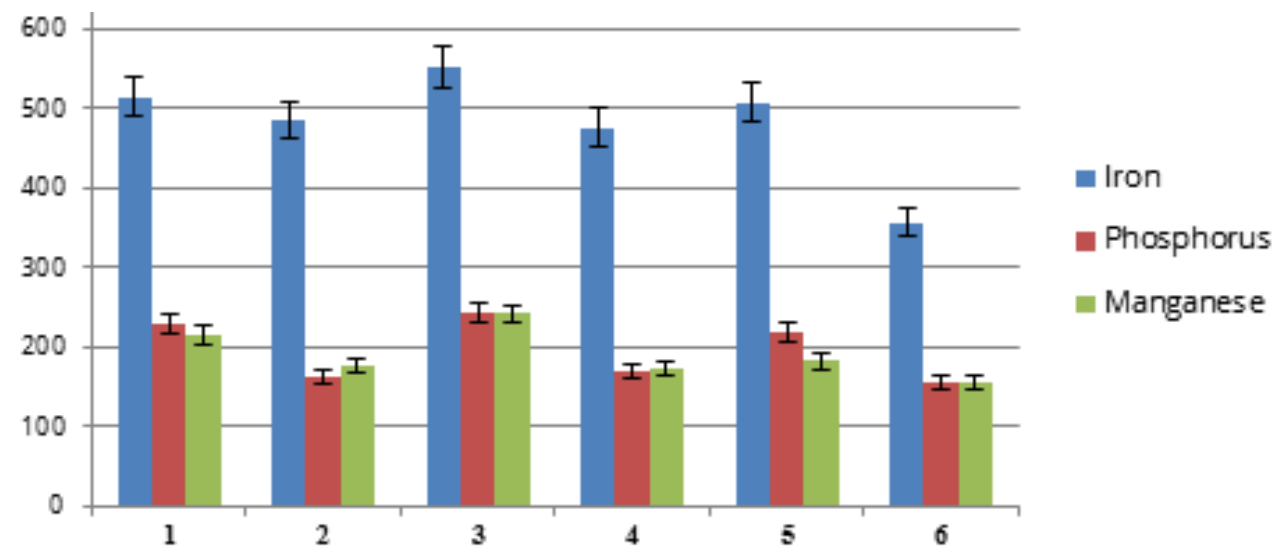

Figure 17. The content of mineral nutrients in the soil substrate when plant waste inoculated with microorganisms, mg/l of soil is applied. Apple waste: 1 - control, 2 - Trichoderma koningii. Grape waste: 3 - control, 4 - T. hamatum. Beet waste: 5 - control, 6 - mixture of Penicillium roseopurpureum + T. hamatum + Cytophaga sp. 


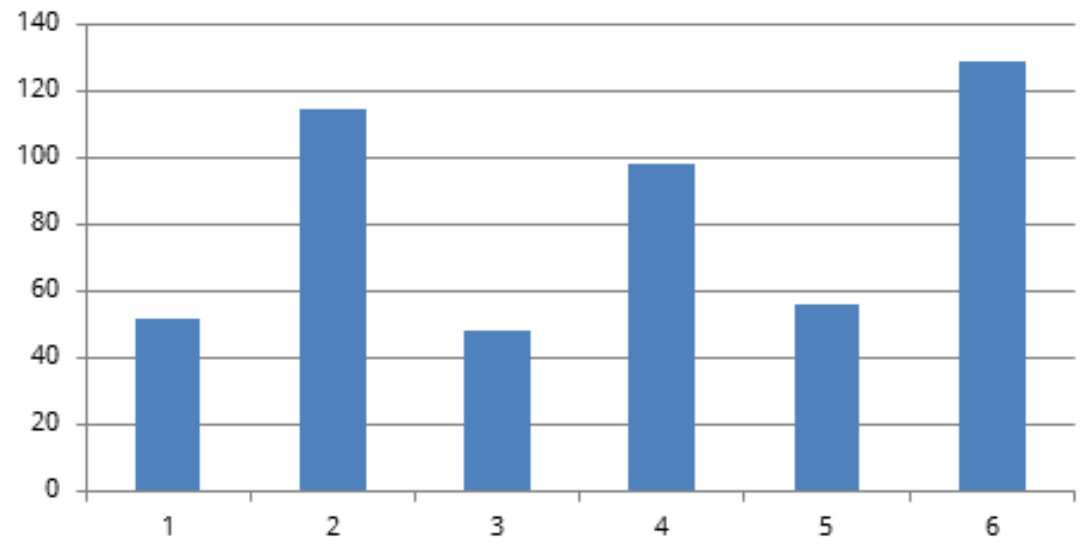

Figure 18. Phytotoxicity of soil substrate with the application of plant waste inoculated with microorganisms, $\%$ to control (the growth of watercress roots). Apple waste: 1 - control, 2 - Trichoderma koningii. Grape waste: 3 - control, 4 - T. hamatum. Beet waste: $\mathbf{5}$ - control, $\mathbf{6}$ - mixture of Penicillium roseopurpureum + Trichoderma hamatum + Cytophaga sp.

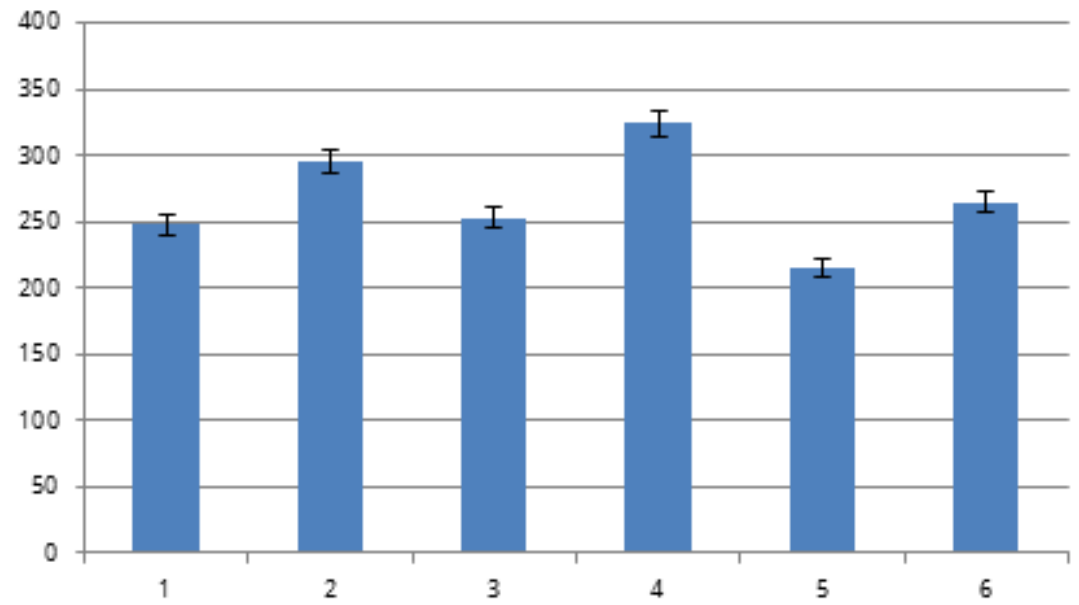

Figure 19. The redox potential of soil substrate (ORP) with the application of plant waste inoculated with microorganisms, mV. Apple waste: 1 - control, 2 - Trichoderma koningii. Grape waste: 3 - control, 4-T. hamatum. Beet waste: 5 - control, 6 - mixture of Penicillium roseopurpureum + T. hamatum + Cytophaga sp.

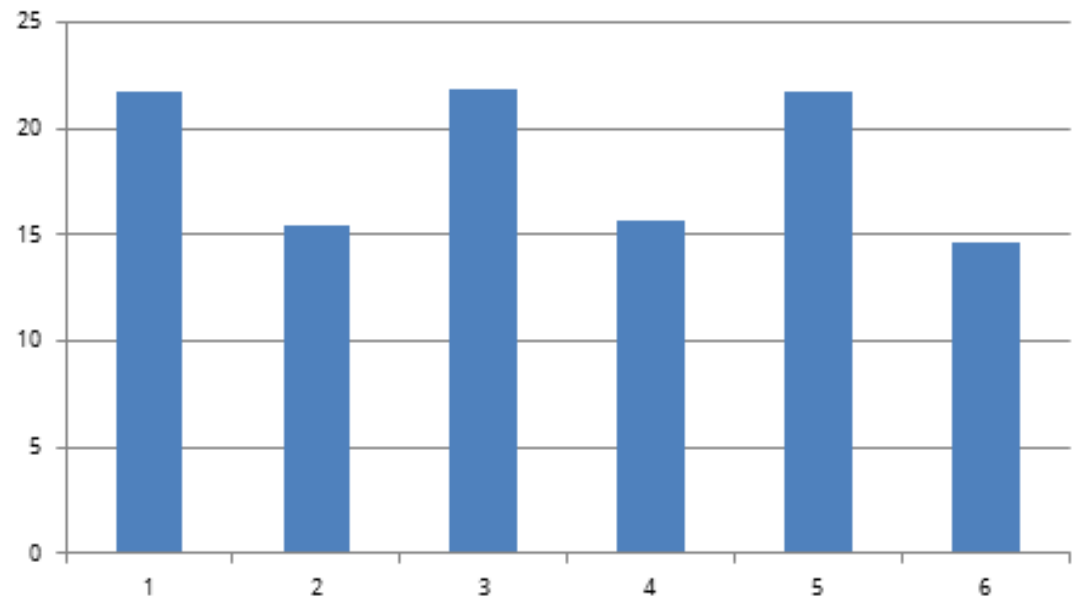

Figure 20. The content of labile organic matter (C) in the soil substrate with the application of plant waste inoculated with microorganisms, \%. Apple waste: 1 - control, 2 - Trichoderma koningii. Grape waste: 3 control, $4-T$. hamatum. Beet waste: 5 - control, 6 - mixture of Penicillium roseopurpureum + T. hamatum + Cytophaga sp. 


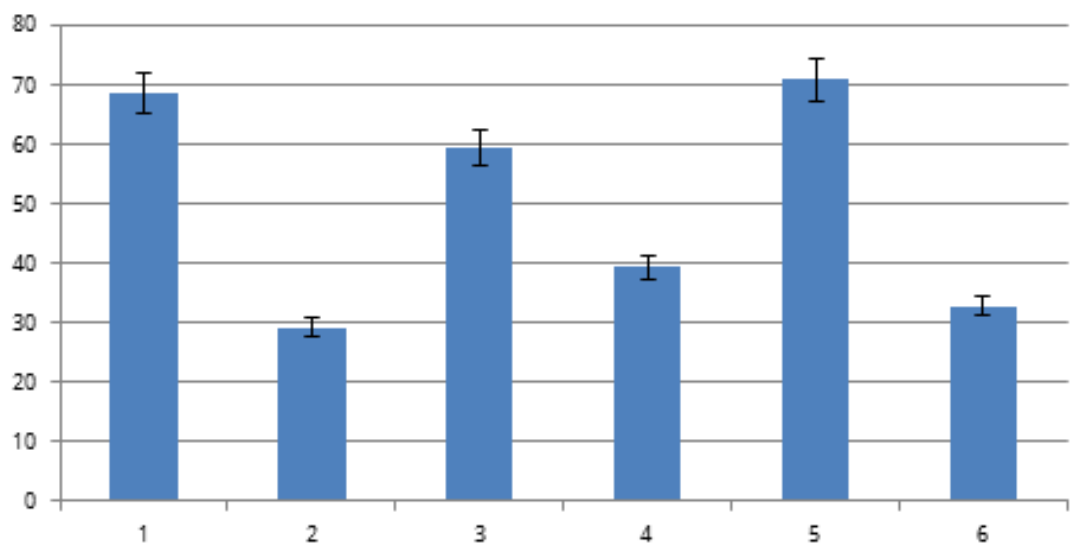

Figure 21. The content of phenolic compounds in the soil substrate with the application of plant waste inoculated with microorganisms, mg/kg. Apple waste: 1 - control, 2 - Trichoderma koningii. Grape waste: 3 - control, 4 - Trichoderma hamatum. Beet waste: 5 - control, 6 - mixture of Penicillium roseopurpureum + Trichoderma hamatum + Cytophaga sp.

substrate was determined by microbiological transformation of plant waste. It was found that the concentration of phenols in the soil in the presence of waste inoculated with microorganisms decreased (Fig. 21).

Obviously, the utilization of waste by microorganisms is a relatively rapid process due to mobile phenolic compounds being involved in humification processes.

The obtained results are consistent with the data on phytotoxicity and prove the feasibility of using plant residues inoculated with microorganisms without negative consequences for the environment but with a positive effect on the nutrient and redox regime of the soil. The analysis of the influence of destructive microorganisms on the transformation of plant waste revealed the inhibitory effect of selected strains of micromycetes and bacteria on the soil substrate's phytotoxicity.

\section{Conclusions}

Based on our studies' data, we propose a unique technology of utilization that consists of specialized strains of microorganisms and suspensions of bacterial cells, immobilized on the crushed silicon-containing mineral analcime. The mineral prepared using our methodology was mixed with vegetable waste in a ratio of 1:10. The most significant destructive activity against apple and grape waste was shown by the strain of Trichoderma hamatum, for beet waste - Penicillium roseopurpureum. The lowest activity was recorded for the strain of $\mathrm{T}$. koningii in the variant with apple waste; for the association of strains of P. roseopurpureum + T. hamatum + Cytophaga sp. - with grape waste; and for T. hamatum strain - with beet waste.

We showed the species-specificity of microorganisms regarding the destruction of plant remains and stimulating plant development effects during their application. It was found that the optimal time for the transformation of plant waste using the proposed technology is 20-30 days. In indoor farming conditions for the preparation of soil substrates, the application norm of the modified vegetable waste is $10 \%$ of the total volume of the mixture.

We proved the environmental safety in the use of plant waste after destruction by microorganisms immobilized on analcime. The presence of silicon-containing mineral analcime in plant waste has a positive effect on plant development by increasing plant resistance to stress factors and improving the state of the soil ecosystem. In particular, silicon-containing mineral analcime reduced soil fatigue and toxicity, optimizing the soil's agrochemical, agrophysical, and biological characteristics. It has been found out that the use of plant waste inoculated with microorganisms increases soil fertility.

The presence of analcime in plant waste, on which the spores of Trichoderma are immobilized, improves soil moisture conservation. Hence, silicon-containing 
mineral analcime provided with mineral nutrients has a strong positive effect on plant growth and development.

\section{References}

Alshaal, T., El-Ramady, H., Al-Saeedi, A. H., Shalaby, T., Elsakhawy, T., Omara, A. E.-D., Gad, A., Hamad, E., El-Ghambry, A., Mosa, A., Amer, M., \& Abdalla, N. (2017). The rhizosphere and plant nutrition under climate change. In M. Naeem, A. Ansari, \& S. Gill (Eds.), Essential plant nutrients (pp. 275-308). Cham: Springer. https:// doi.org/10.1007/978-3-319-58841-4_11

Angulo, J., Mahecha, L., Yepes, S. A., Yepes, A. M., Bustamante, G., Jaramillo, H., Valencia, E., Villamil, T., \& Gallo, J. (2012). Quantitative and nutritional characterization of fruit and vegetable waste from marketplace: A potential use as bovine feedstuff? Journal of Environmental Management, 95, 203-209. https://doi. org/10.1016/j.jenvman.2010.09.022

Atlas, R. M. (2005). Handbook of media for environmental microbiology. $2^{\text {nd }}$ ed. Boca Raton: CRC Press.

Baiano, A. (2014). Recovery ofbiomolecules fromfood wastes - a review. Molecules, 19(9), 14821-14842. https://doi.org/10.3390/molecules190914821

Blum, U. (2004). Fate of phenolic allelochemicals in soils - the role of soil and rhizosphere microorganisms. In F. A. Macias (Ed.), Allelopathy: Chemistry and mode of action of allelochemicals (pp. 57-76). CRC Press.

Du, H., \& Li, F. (2016). Size effects of potato waste on its treatment by microbial fuel cell. Environmental Technology, 37(10), 1305-1313. https://doi.org/10 .1080/09593330.2015.1114027

El-Ramady, H. R., Alshaal, T. A., Amer, M., DomokosSzabolcsy, É., Elhawat, N., Prokisch, J., \& Fári, M. (2014). Soil quality and plant nutrition. In $\mathrm{H}$. Ozier-Lafontaine, \& M. Lesueur-Jannoyer (Eds.), Sustainable agriculture reviews. Vol. 14: Agroecology and global change (pp. 345-447). Cham: Springer. https://doi.org/10.1007/978-3-319-06016-3_11

Fiedler, S., Vepraskas, M. J., \& Richardson, J. L. (2007). Soil redox potential: Importance, field measurements and observations. Advances in Agronomy, 94, 1-54. https://doi.org/10.1016/ S0065-2113(06)94001-2

Fisgativa, H., Tremier, A., Le Roux, S., Bureau, C., \& Dabert, P. (2017). Understanding the anaerobic biodegradability of food waste: Relationship between the typological, biochemical and microbial characteristics. Journal of Environmental Management, 188, 95-107. https://doi. org/10.1016/j.jenvman.2016.11.058
Gavrilov, V.O.,Zaimenko, N.V., \& Slyusarenko, O.M. (2013). Penicillium roseopurpureum mushroom strain - culvularin producer. Patent for the invention UA № 100804, Bul. N 2. (In Ukrainian)

Grodzinskij, A. M., Gorobec, S. A., \& Krupa, L. I. (1988). Guidance on the application of biochemical methods in allelopathic studies of soil. Kyiv. (In Russian)

Grodzinskij, A. M., Kostroma, E. J., Shrol, T. S., \& Hohlova, I. G. (1990). Direct bioassay methods of soil and microorganisms metabolites. In Allelopathy and plant productivity: Collection of scientific papers (pp. 121-124). Kyiv: Naukova Dumka. (In Russian)

Hasanuzzaman, M., Nahar, K., Rahman, A., Mahmud, J. A., Hossain, M. S., Alam, M. K., Oku, H., \& Fujita, M. (2017). Actions of biological trace elements in plant abiotic sress tolerance. In M. Naeem, A. Ansari, \& S. Gill (Eds.), Essential plant nutrients (pp. 213-274). Cham: Springer. https://doi.org/10.1007/978-3-319-58841-4_10

Hernon, F., Forbes, C., \& Colleran, E. (2006). Identification of mesophilic and thermophilic fermentative species in anaerobic granular sludge. Journal of the International Association on Water Pollution Research: Water Science and Technology, 54(2), 19-24. https://doi.org/10.2166/ wst.2006.481

Labuda, S. Z., \& Vetchinnikov, A. A. (2011). Soil susceptibility on reduction as an index of soil properties applied in the investigation upon soil devastation. Ecological Chemistry and Engineering S, 18(3), 333-344.

Laufenberg, G., Kunz, B., \& Nystroem, M. (2003). Transformation of vegetable waste into value added products: (A) the upgrading concept; (B) practical implementations. Bioresource Technology, 87(2), 167-198. https://doi.org/10.1016/s09608524(02)00167-0

Li, Z.-H., Wang, Q., Ruan, X., Pan, C.-D., \& Jiang, D.A. (2010). Phenolics and plant allelopathy. Molecules, 15(12), 8933-8952. https://doi. org/10.3390/molecules15128933

Lu, W.J., Wang, H. T., Yang, S. J., Wang, Z. C., \& Nie, Y. F. (2005). Isolation and characterization of mesophilic cellulose-degrading bacteria from flower stalksvegetable waste co-composting system. Journal of General and Applied Microbiology, 51(6), 353-360. https://doi.org/10.2323/jgam.51.353

Lu, W., Hesham, A. E., Zhang, Y., Liu, X., \& Yang M. (2011). Impacts of cell surface characteristics on population dynamics in a sequencing batch yeast reactor treating vegetable oilcontaining wastewater. Applied Microbiology and Biotechnology, 90(5), 1785-1793. https://doi. org/10.1007/s00253-011-3206-6 
Motta, F. L., \& Santana, M. H. (2013). Production of humic acids from oil palm empty fruit bunch by submerged fermentation with Trichoderma viride: Cellulosic substrates and nitrogen sources. Biotechnology Progress, 29(3), 631-637. https:// doi.org/10.1002/btpr.1715

Naeem, M., Ansari, A., Gill, S. S., Afrab, T., Idress, M., Ali, A., \& Khan, M. M. A. (2017). Regulatory role of mineral nutrients in nurturing of medicinal legumes under salt sress. In M. Naeem, A. Ansari, \& S. Gill (Eds.), Essential plant nutrients (pp. 309-334). Cham: Springer. https://doi. org/10.1007/978-3-319-58841-4_12

Naseer, R., Sultana, B., Khan, M. Z., Naseer, D., \& Nigam, P. (2014). Utilization of waste fruitpeels to inhibit aflatoxins synthesis by Aspergillus flavus: A biotreatment of rice for safer storage. Bioresource Technology, 172, 423-428. https://doi. org/10.1016/j.biortech.2014.09.017

Pandit, P. D., Gulhane, M. K., Khardenavis, A. A., \& Purohit, H. J. (2016). Mining of hemicellulose and lignin degrading genes from differentially enriched methane producing microbial community. Bioresource Technology, 216, 923-930. https://doi.org/10.1016/j.biortech.2016.06.021

Pospisil, F., Cvikrova, M., Hrubcova, M., \& Sindelarova, M. (1981). Soluble phenolic and humic substances in the soil and their effect on metabolism in plants. In V. I. Kefeli (Ed.), Plant growth and differentiation (pp. 150-161). Moscow: Nauka. (In Russian)
Powlson, D. S., Riche, A. B., Coleman, K., Glendining, M. J., \& Whitmore, A. P. (2008). Carbon sequestration in European soils through straw incorporation: Limitations and alternatives. Waste Management, 28(4), 741-746. https://doi.org/10.1016/j.wasman.2007.09.024

Rinkis, G. J., \& Nollendorf, V. F. (1982). Balanced nutrition of plants with macro- and microelements. Riga: Zinatne. (In Russian)

Ros, M., Franke-Whittle, I. H., Morales, A. B., Insam, H., Ayuso, M., \& Pascual, J. A. (2013). Archaeal community dynamics and abiotic characteristics in a mesophilic anaerobic co-digestion process treating fruit and vegetable processing waste sludge with chopped fresh artichoke waste. Bioresource Technology, 136, 1-7. https://doi.org/10.1016/j. biortech.2013.02.058

Ryckeboer, J., Mergaert, J., Coosemans, J., Deprins, K., \& Swings, J. (2003). Microbiological aspects of biowaste during composting in a monitored compost bin. Journal of Applied Microbiology, 94(1), 127-137. https://doi. org/10.1046/j.1365-2672.2003.01800.x

Sathishkumar, P., Murugesan, K., \& Palvannan, T. (2010). Production of laccase from Pleurotus florida using agro-wastes and efficient decolorization of Reactive blue 198. Journal Basic Microbiology, 50(4), 360-367. https://doi. org/10.1002/jobm.200900407

\section{Сучасна біотехнологія в оптимізації утилізації рослинних відходів}

Наталія Заіменко 1, *, Богдана Іваницька ${ }^{1}$, Наталія Павлюченко ', Олександр Слюсаренко 2, Ліцзюань Тянь ${ }^{3}$, Тяньлінь Мяо ${ }^{3}$, Децзян Лю ${ }^{3}$, Мирон Пизик ${ }^{4}$, Ян Сласкі ${ }^{5}$

${ }^{1}$ Національний ботанічний сад імені М.М. Гришка НАН України, вул. Тимірязєвська, 1, Київ, 01014, Україна; *zaimenkonv@ukr.net

2 Ботанічний сад Одеського національного університету імені І.І. Мечникова, Французький бульвар, 48/50, Одеса, 65058, Україна

${ }^{3}$ Китайсько-Українська міжнародна спільна лабораторія з розробки та застосування технології для сільського й лісового господарства, Цзямуський університет, Цзямуси, 154007, Китай

${ }^{4}$ Об'єднаний інститут сучасних технологій, Едмонтон, Альберта, Т5N 3C1, Канада

${ }^{5}$ Відділ біопромислових послуг, Інно Тех Альберта, Вегревіль, Альберта, Т9С 1Т4, Канада

Метою дослідження було розробити сучасну, дешеву та екологічно безпечну технологію утилізації рослинних відходів за допомогою найактивніших мікроорганізмів-деструкторів.

Було ретельно вивчено здатність мікроорганізмів перетворювати рослинні відходи на родючий ґрунт. Було відібрано штами мікроміцетів Penicillium roseopurpureum, Trichoderma hamatum, T. koningii, 
Alternaria alternata та бактерії роду Cytophaga, які характеризуються високою швидкістю росту та відсутністю фітотоксичності. Для прискорення швидкості розвитку мікроорганізмів було використано кремнійвмісний мінерал анальцим, який містив іммобілізовані спори мікроміцетів і суспензію бактеріальних клітин. Модифікований анальцим додавали до відходів у співвідношенні $10: 1$. Підготовлені за цим методом рослинні рештки аналізували в умовах як модельних, так $\mathrm{i}$ вегетаційних експериментів.

Було продемонстровано доцільність використання кремнійвмісного мінералу анальциму як вихідного субстрату для іммобілізації спор і суспензії бактеріальних клітин у культуральній рідині. Мікроорганізми застосовані в експерименті, показали позитивний результат під час трансформації рослинних відходів протягом 30-денного періоду спостереження. Найвища деструктивна активність щодо відходів яблуні та винограду характерна для штаму T. hamatum, а щодо бурякових відходів - для P. roseopurpureum. Було встановлено видову специфіку цих мікроорганізмів-деструкторів у процесах росту рослин. Максимальний приріст кукурудзяних паростків у яблучних відходах було виявлено у разі інокуляції спорами T. koningii, у виноградних відходах - T. hamatum, а у бурякових відходах - сумішшю мікроміцетів із суспензією Cytophaga sp. Оптимальна тривалість трансформації рослинних відходів за допомогою анальциму, інокульованого мікроорганізмами, становила 20-30 днів. В умовах закритого ґрунту стандарт утилізації модифікованих рослинних відходів становив 10 \% від загального обсягу субстрату під час приготування ґрунтових сумішей.

У результаті виконаних досліджень підтверджено екологічну безпеку рослинних відходів після їхньої деструкції. Наявність у суміші кремнійвмісного мінералу сприяє посиленню росту та розвитку рослин, оптимізації агрофізичних, агрохімічних та біологічних параметрів ґрунту, зменшенню ґрунтовтоми, а також підвищенню родючості. 